Connecting Section and Associated Systems Concept for the Spray Calciner/In-Can Melter Process
L. L. Petkus
P. S. Gorton
H. T. Blair

June 1981

Prepared for the U.S. Department of Energy under Contract DE-ACO6-76RLO 1830

Pacific Northwest Laboratory Operated for the U.S. Department of Energy by Battelle Memorial Institute 
NOTICE

This report was prepared as an account of work sponsored by the United States Government. Neither the United States nor the Department of Energy, nor any of their employees, nor any of their contractors, subcontractors, or their employees, makes any warranty, express or implied, or assumes any legal liability or responsibility for the accuracy, completeness or usefulness of any information, apparatus, product or process disclosed, or represents that its use would not infringe privately owned rights.

The views, opinions and conclusions contained in this report are those of the contractor and do not necessarily represent those of the United States Government or the United States Department of Energy.

\author{
PACIFIC NORTHWEST LABORATORY \\ operated by \\ BATTELLE \\ for the \\ UNITED STATES DEPARTMENT OF ENERGY \\ Under Contract DE-AC06-76RLO 1830
}

\author{
Printed in the United States of America \\ Available from \\ National Technical information Service \\ United States Department of Commerce \\ 5285 Port Royal Road \\ Springfield. Virginia 22151
}

Price: Printed Copy 5

$\therefore$ Microfiche $\$ 3.00$

NTIS

-Pages Selling Price

$\begin{array}{lr}001-025 & \$ 4.00 \\ 026-050 & \$ 4.50 \\ 051-075 & \$ 5.25 \\ 076-100 & \$ 6.00 \\ 101-125 & \$ 6.50 \\ 126-150 & \$ 7.25 \\ 151-175 & \$ 8.00 \\ 176-200 & \$ 9.00 \\ 201-225 & \$ 9.25 \\ 226-250 & \$ 9.50 \\ 251-275 & \$ 10.75 \\ 276-300 & \$ 11.00 \\ & \end{array}$


PNL -3170

UC -70

\title{
33679000537839
}

\section{CONNECTING SECTION AND ASSOCIATED SYSTEMS CONCEPT FOR THE SPRAY CALCINER/IN-CAN \\ MELTER PROCESS}

\author{
L. L. Petkus \\ P. S. Gorton \\ H. T. Blair
}

June 1981

Prepared for

the U.S. Department of Energy

under Contract DE-AC06-76RLO 1830

Pacific Northwest Laboratory

Richland, Washington 99352 


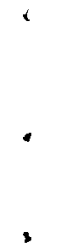




\section{SUMMARY}

For a number of years, researchers at the Pacific Northwest Laboratory have been developing processes and equipment for converting high-level liquid wastes to solid forms. One of these processes is the Spray Calciner/In-Can Melter system. To immobilize high-level liquid wastes, this system must be operated remotely, and the calcine must be reliably conveyed from the calciner to the melting furnace. A concept for such a remote conveyance system was developed at the Pacific Northwest Laboratory, and equipment was tested under full-scale, nonradioactive conditions. The report here describes this concept and the design of demonstration equipment and presents the results of equipment operation during experimental runs of $7 \mathrm{~d}$. The design includes a connecting section and $i$ ts associated systems--a canister support and alignment concept and a weight-monitoring system for the melting furnace.

Remote coupling of the connecting section to the canister and modified canister handling were demonstrated during the runs. No misalignment problems were encountered. The retraction mechanism of the connecting section was not as reliable as desired as a result of the accumulation of calcine. However, all canister exchanges were completed as necessary for the continuity of the runs.

The connecting section maintained the process envelope during the fill and canister exchange activities as well as can be determined by the process instrumentation. Some calcine leakage was noted at the spout/cone valve interface, probably due to warping of the cone valve. Airflow through this small leak was not noticeable by process offgas instrumentation.

In this design, the canister sits on the bottom of the furnace. To monitor fill of the canister, the whole furnace is weighed by two systems, one which monitors small weight gains for instantaneous fill rate and one which monitors total furnace weight. The instantaneous weight-gain system produced too much noise to monitor the small weight changes that occurred. However, all side torques, thermal expansion and misalignment problems were isolated from the total weight system so that the long-term changes were quite visible. 
During these runs, the flow of batch and offgasses through the delivery tube assembly of the connecting section was unhindered during the operating periods. The spout and cone-valve cooling system, after modification, provided better temperature control although the cooling was still not adequate for dependable operation.

Overall, the runs demonstrated that the concept design is an acceptable method of connecting the two pieces of process equipment together. Although the connecting section has not been optimized in all areas of concern, it provides a first-generation design of a production-oriented system. 


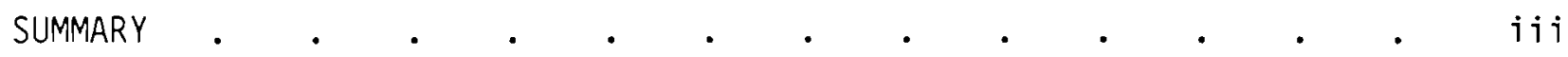

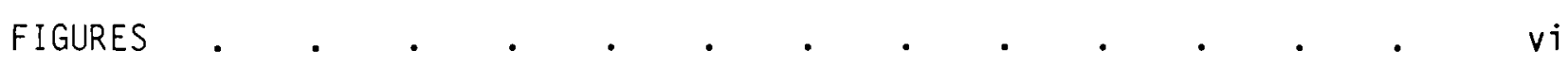

INTRODUCTION

CONNECTING SECTION AND ASSOCIATED SYSTEMS CONCEPT • • • • • • • • 5

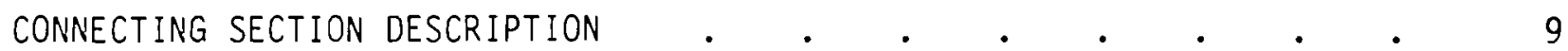

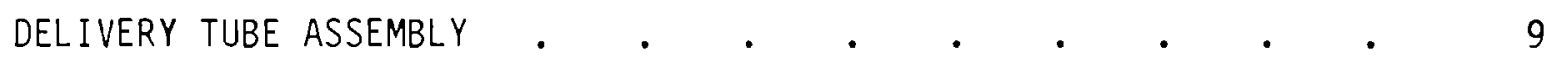

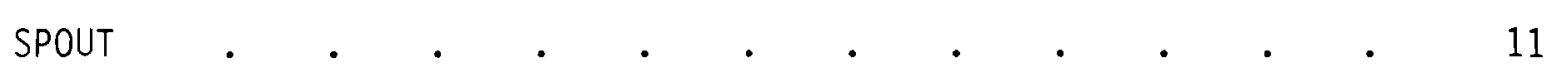

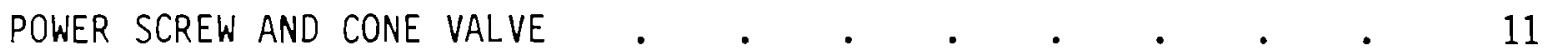

CONNECTING SECTION/CANISTER INTERFACE SEAL $\quad$ - $\quad \cdot \quad \cdot \quad \cdot \quad \cdot \quad 18$

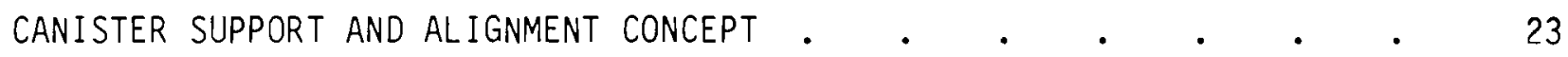

ACCOMMODATION OF CANISTER MISALIGNMENT AND EXPANSION

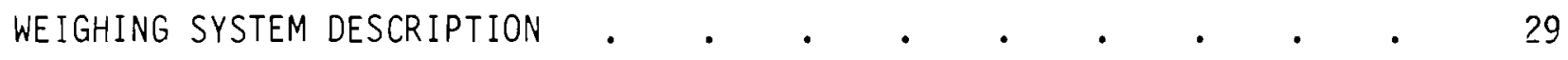

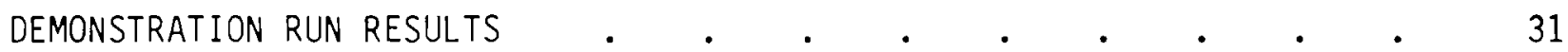

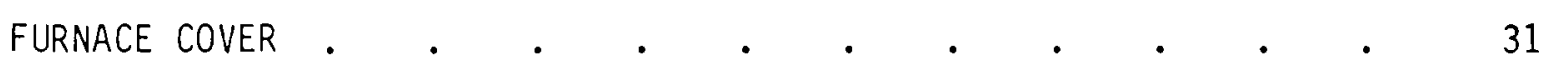

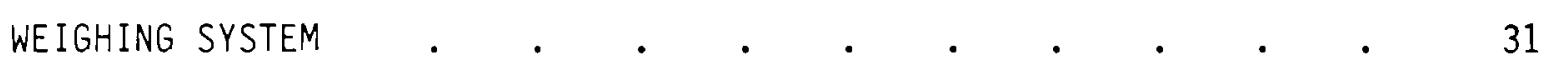

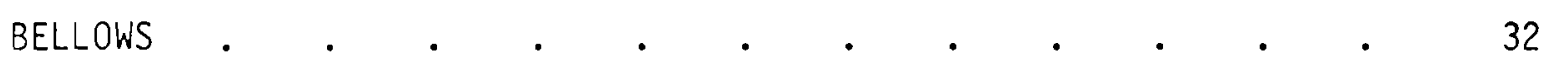

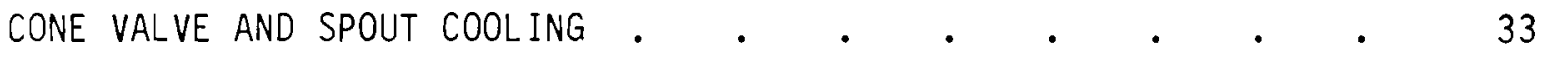

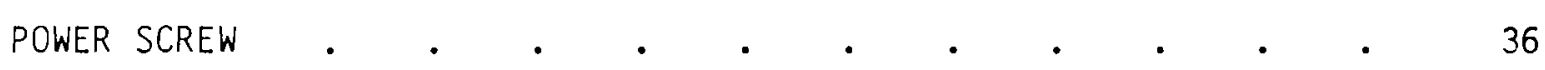

THERMOCOUPLES

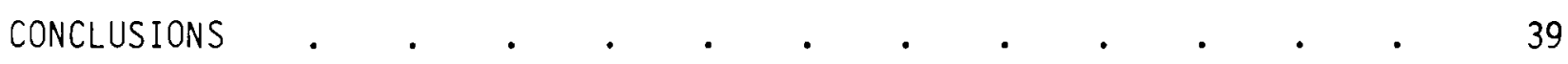

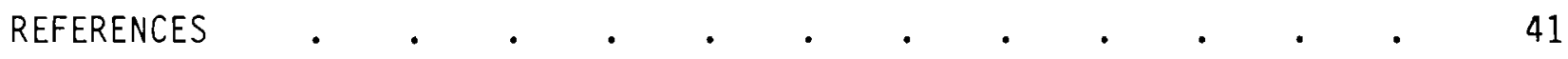

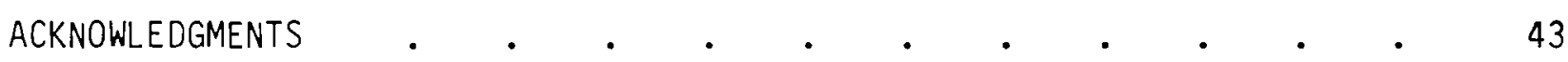




\section{FIGURES}

1 Spray Calciner/In-Can Melter Process . . . . . . 2

2 Full-Scale Spray Calciner and In-Can Melter at PNL . . . 3

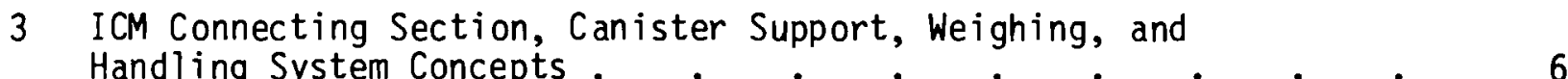

4 Conceptual Delivery Tube Assembly . $\quad$. $\quad . \quad$. $\quad . \quad$. $\quad$. 10

5 Conceptual Connecting Section Mechanism . . . . . . 12

6 Cage and Extended Spout . . . . . . . . . . . 13

7 Upper Portion of the Connecting Section . . . . . . . 14

8 Conceptual Spout and Cone-Valve Assembly . . . . . . 15

9 Cone-Valve Actuation Assembly . • . . . . . . . . 17

10 Pivot Arm Actuator . . . . . . . . . . . . 19

11 Connecting Section/Canister Interface . . . . . . 20

12 ICM Canister Support Concept . . . . . . . . . 24

13 Limits of Possible Seal Axis Position . . . . . . . 25

14 Accommodation of Connecting Section to Canister 
$\underline{\text { INTRODUCTION }}$

Processes and equipment for the conversion of high-level liquid wastes to solid forms have been under development for many years at the Pacific Northwest Laboratory (PNL), operated by Battelle Memorial Institute for the Department of Energy. Figure 1 illustrates one of the more fully developed processes that uses a heated-wall spray calciner to convert liquid waste to a dry powder. A glass-forming frit is added to the powder, and the blend is fed continuously into a canister contained in a heated, multizone furnace where the blend melts. The process is called in-can melting, and the canister and furnace an in-can melter (ICM). Since the calciner is operated continuously and the batches of blend are fed into the ICM, the process allows the coupling of two ICMs to the calciner at a diverter. Once one canister is filled with melt, the blend of calcined waste and frit is diverted to the second ICM. As the melt in the filled canister cools, it forms a leach-resistant borosilicate glass containing the waste elements in its structure. Then, the filled canister is removed from the furnace, sealed, decontaminated, and transported to a waste storage facility.

This Spray Calciner/In-Can Melter (SC/ICM) process has been developed to the state that full-scale, nonradioactive equipment (see Figure 2) was procured and made operational at PNL in April 1977. In September of that year, the equipment was operated continuously for $10 \mathrm{~d}$ (Blair, Gorton and Nelson 1979). During this demonstration, 12 canisters were filled with simulated vitrified waste. At that time, we recognized the need to develop a fully remote, operated connecting section to facilitate the exchange of canisters, and that the key to successful remote operations of this connecting section was the alignment of the canister in the furnace with a coupling device. However, existing methods of achieving the desired alignment and of applying a sealing force to the junction of the canister and connecting section affected the system used to monitor the weight of the contents of the ICM as it was filled. Therefore, a completely integrated design was needed that included a remotely operated connecting section, a canister support and alignment concept, and a weightmonitoring system for the ICM. 


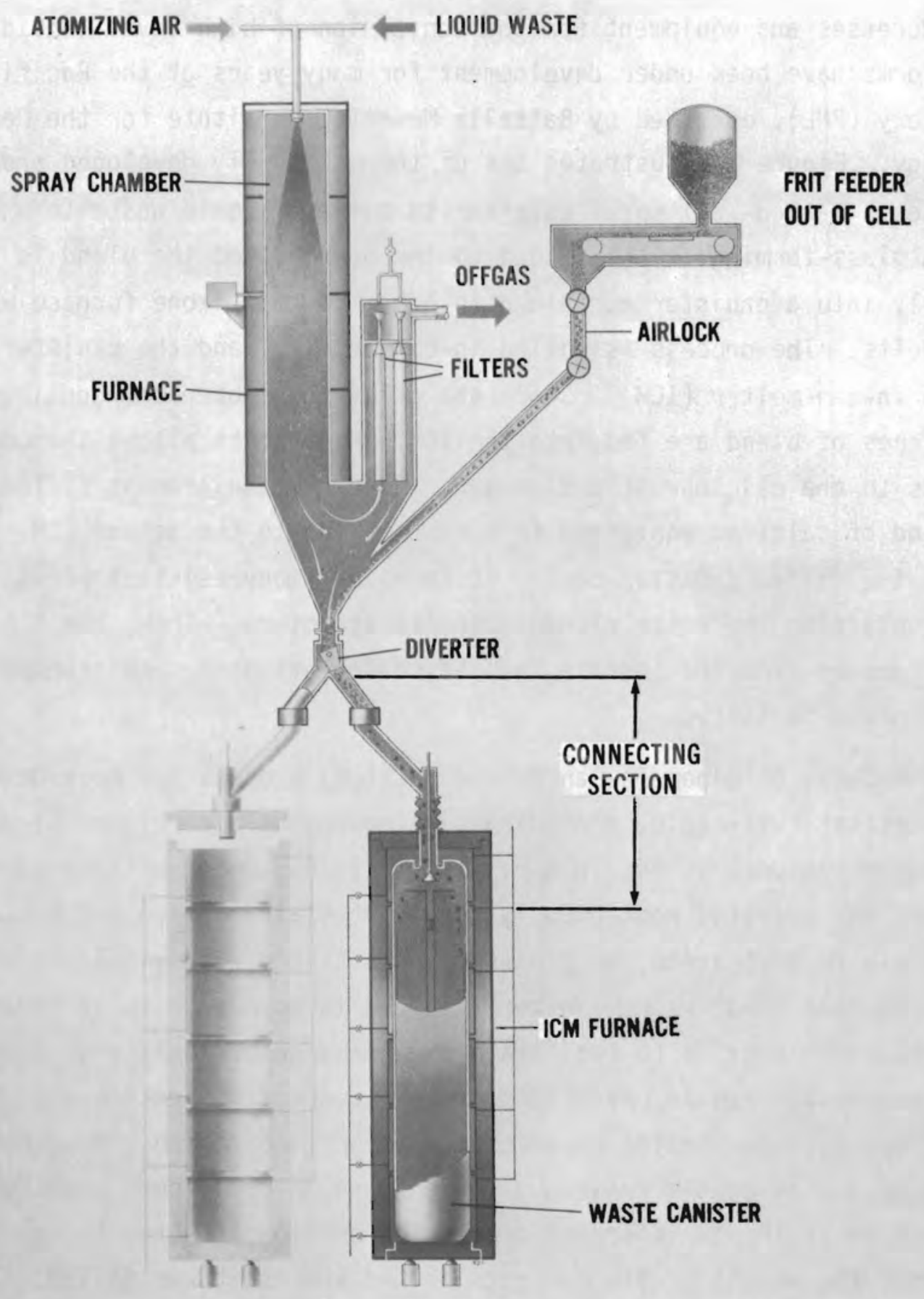

FIGURE 1. Spray Calciner/In-Can Melter Process 


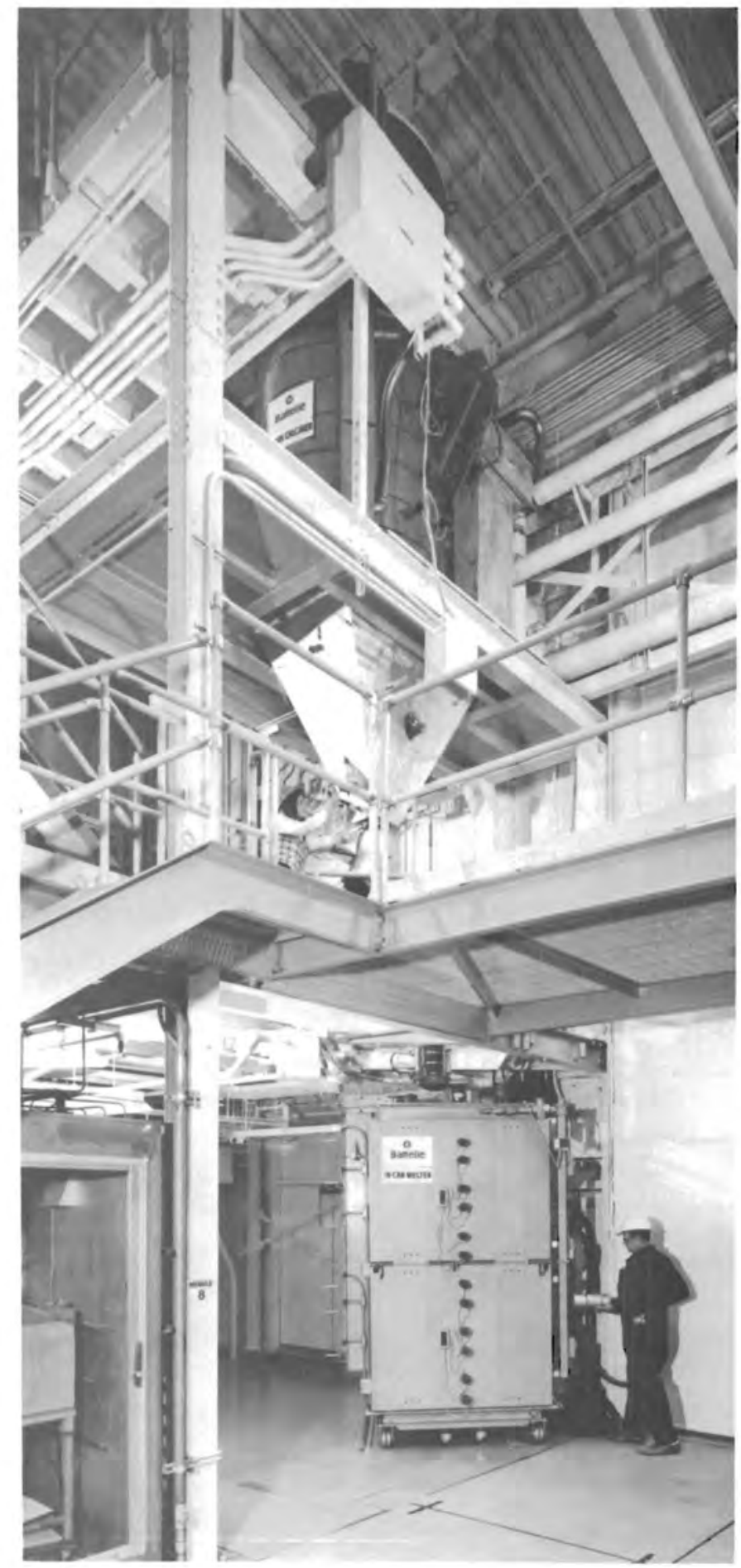

FIGURE 2. Full-Scale Spray Calciner and In-Can Melter at PNL 
This integrated design would help meet the specific objectives of demonstrating the remote operation of the SC/ICM process:

- continuous operation of the calciner;

- a stationary ICM furnace;

- bottom support of the canister in the furnace;

- complete canister submersion in the furnace hot zone;

- monitoring of the melter weight gain for process control;

- remote operation with an overhead crane and an air wrench;

- durability in an environment characterized by radiation $\left(10^{6} \mathrm{rad} / \mathrm{h}\right.$ gamma, $200 \mathrm{rad} / \mathrm{h}$ neutron), high humidity, sustained temperatures from $120^{\circ} \mathrm{C}$ to $1070^{\circ} \mathrm{C}$, and nitric acid contamination;

- canister exchange without significant release of calcine into the cell.

This document describes a concept for a remotely operable connecting section and its associated systems by providing the design of demonstration equipment. In addition, results are presented of equipment operation during a continuous 5-d run and a subsequent 2-d run, in which six canisters of borosilicate waste glass were produced. 


\section{CONNECTING SECTION AND ASSOCIATED SYSTEMS CONCEPT}

In the SC/ICM concept, a blend of calcined high-level liquid waste and glass-forming frit flows continuously from a calciner into one of two ICMs. This concept allows for the alternate filling of canisters: while one is being filled, the other, already filled, is exchanged for an empty canister. Figure 3 illustrates an envisioned ICM connecting section and canister support, weighing and handling system concept for remote operation in this SC/ICM process.

Each station of this system consists of a connecting section, a stationary furnace, and a weight system. A diverter (Siemens and Bonner 1976) interfaces the two connecting sections to a funnel at the output of the calciner and frit delivery systems. Each connecting section consists of a cone valve, spout, delivery tube, swivel joint, and associated mechanism (to be illustrated later). The spout telescopes on the vertical leg of the delivery tube and is raised and lowered by the cone valve.

The two ICM furnaces are sufficiently offset from the calciner to allow access by an overhead crane. Before an empty canister is lifted and lowered into a furnace, a furnace cover is engaged in the twistlock opening (Blair 1979) of the canister. A sleeve in this cover facilitates remote, nonoriented coupling of a lifting device carried by the overhead crane. The proposed lifting device eliminates the need for angular orientation of the canister in the furnace and simplifies the design of the connecting section.

Once the canister is lowered into the furnace, it rests on its base and is aligned by centering guides in the bottom of the furnace, and the engaged cover is restrained in the furnace opening. The sleeve of the cover is then extended so that the canister is completely submerged inside the furnace. We recognize that canister alignment cannot be closely controlled by these supports because of the $1050^{\circ} \mathrm{C}$ temperature required for vitrification; therefore, the connecting section must accommodate the resulting canister misalignment. 


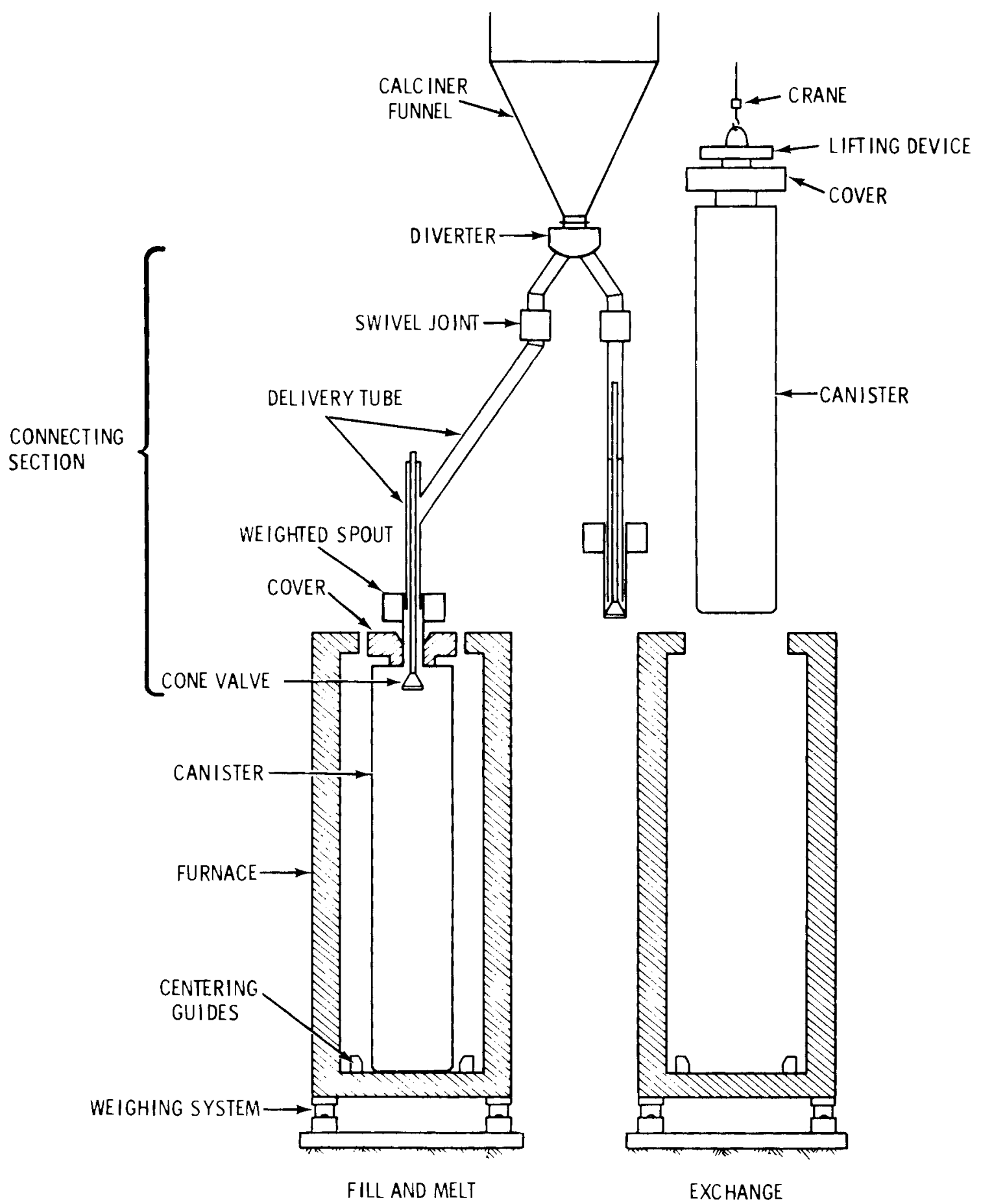

FIGURE 3. ICM Connecting Section, Canister Support, Weighing, and Handling System Concepts 
After the lifting device is removed, one of the two connecting sections is pivoted into position through the cover sleeve, which is appropriately tapered to guide the spout into the canister opening. The connecting section mechanism allows the spout to assume canister alignment and to compress a metallic seal retained in the canister opening. The spout is weighted for the purpose of making the seal. Further lowering of the cone valve opens the spout and prepares the canister to accept batch once the furnace is hot.

Next, batch is diverted into the prepared canister. This batch, gravityfed through the connecting section, impinges on the cone valve, which disperses it around the walls of the canister. This dispersion prevents accumulation of batch on the axis of the heat transfer plate assembly (Blair 1979) in the canister. When the canister is filled, the cone valve and spout are raised, clearing the furnace elevation. The connecting section is pivoted out of the way on its swivel joint, and the overhead crane is lowered for canister removal and exchange.

A weighing system supports the furnace, canister, cover, spout and delivered batch. The telescoping interface between the spout and the delivery tube is designed to allow the spout to move or "float" with the canister while minimizing the transmittal of vertical forces. In this manner, thermal expansion and warpage of the canister during processing are isolated from the weight system. This system directly measures total weight and the rate of weight gain (or fill rate) for process control.

Simultaneous offgassing at both ICM stations is controlled by the diverter valve. This system maintains a vacuum of 10-in. water for this purpose. For a period of time after the flow of batch has been diverted to the next prepared canister, the cone valve is left open to continue offgassing in the filled canister during completion of the melting. Afterwards, as the cone valve is raised, the weight of the spout gradually transfers from the seal at the canister opening to the cone valve, closing the spout. Continuous offgassing in the now closed connecting section is intended to assure that any leakage at this interface will be into the system. 


\section{CONNECTING SECTION DESCRIPTION}

The connecting section mechanism designed for use in the nonradioactive tests consists of three major portions--a delivery tube assembly, a spout, and a power screw and cone valve. The delivery tube assembly transfers the frit and calcine from the diverter valve to the spout. The delivery tube of this assembly must allow for movement at the spout that results from misalignment and thermal expansion. The spout interfaces with the canister in the furnace and is supported by a gimbal to allow the spout to assume a mating position with the canister seal. Finally, the cone valve and power screw provide the motive force to lower the spout onto the canister to make a seal, and then to raise the spout again for canister removal. Each of these pieces of equipment is described in detail. In addition, the mechanics of the seal formed between the spout and canister is explained.

\section{DELIVERY TUBE ASSEMBLY}

Universal movement of the delivery tube at the spout/canister interface is facilitated by flexible joints in its sloped leg (Figure 4). The upper joint accommodates universal pivoting and supports the weight of the sloped tube. The lower joint is a combination universal-pivoting and telescoping joint that accommodates desired movement along with thermal expansion of the sloped tube. Both joints incorporate flexible metal bellows to seal the delivery tube and internal sleeves to protect the bellows from direct contact with batch flow.

A bracket extending from the pivot arm supports the upper portion of the sloped tube. Also, this bracket prevents transmittal of the swivel torque to the bellows in the sloped tube. An expansion bellows above the swivel joint accommodates connecting section "fit-up" to the diverter and thermal expansion of the diverter and calciner funnel. Swivel torque is isolated from this bellows by three studs, and an internal sleeve protects the bellows from direct contact with batch flow. 


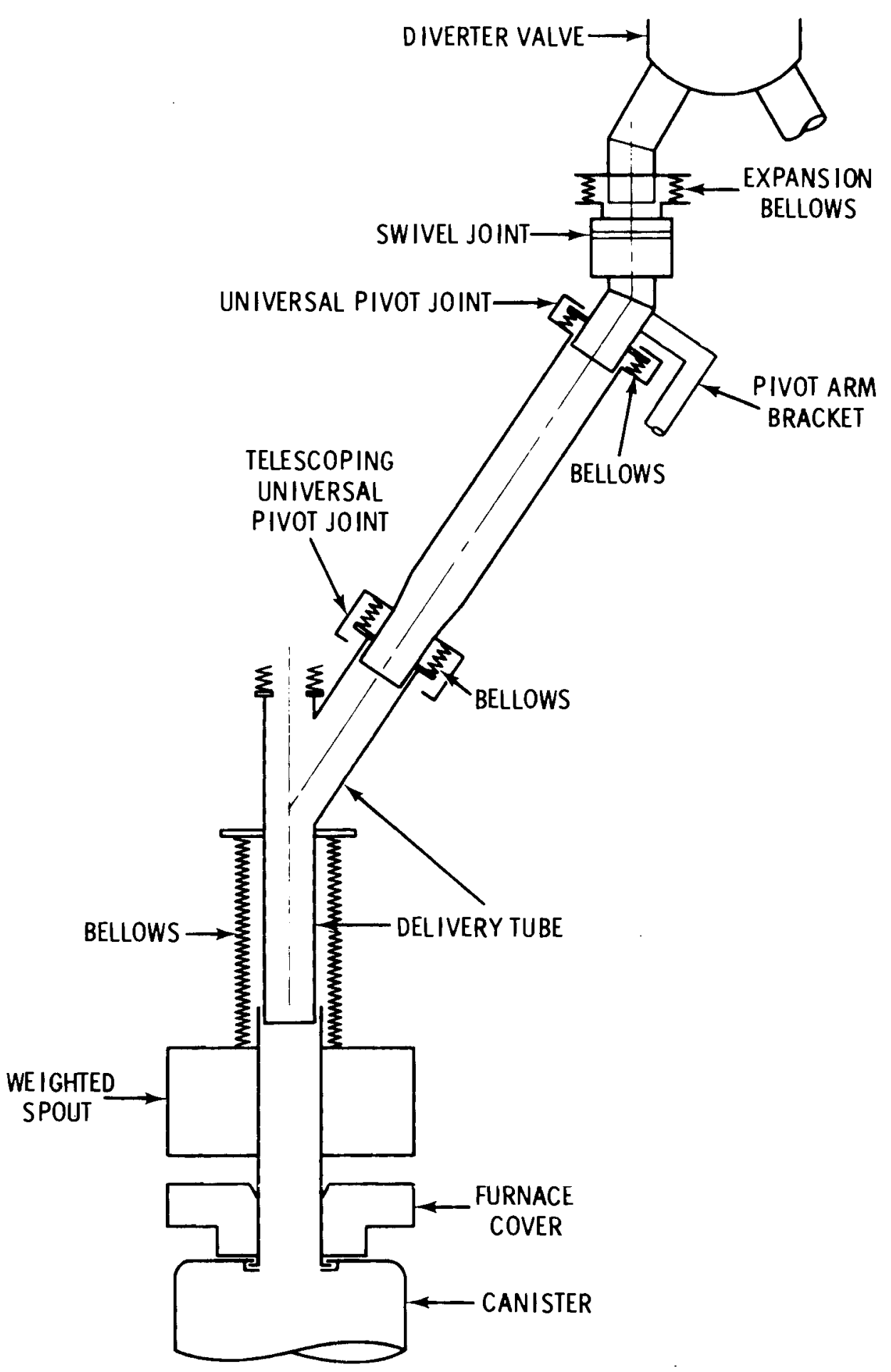

FIGURE 4. Conceptual Delivery Tube Assembly 
Figure 5 illustrates the connecting section engaged with a canister in the furnace. In this position, the weighted spout is extended on the vertical leg of the delivery tube through the cover and supported by the canister. A flexible metal bellows seals the telescoping spout to the delivery tube. A cylindrical cage, integrated with the delivery tube, contains two vertical ways for cam-followers attached to the spout weight. This arrangement prevents the bellows from being twisted by the spout during engagement with a tilted canister. Figure 6 shows the cage and fully extended spout supported on the cone valve prior to positioning in the furnace. (Because of structural constraints, during the demonstrations the furnace was moved on an air pallet from its normal connecting-section position to an adjacent high-bay where the canister was exchanged using an overhead crane.)

In Figure 5, the cone-valve stem extends through the vertical leg of the delivery tube and is attached to a linear slide. Another flexible metal bellows seals this slide to the vertical delivery tube. The slide moves on two vertical shafts (partially shown) that are contained in a frame that supports the valve actuator located on the axis of the cone-valve stem. The frame is supported by the pivot arm through gimbal. The actuator, shafts, slides and gimbal are shown in Figure 7, which is a view of the upper portion of the connecting section attached to the diverter valve below the calciner funnel.

The gimbal facilitates spout alignment with the canister seal by allowing the delivery tube, which extends into the upper opening of the spout, to move universally with the spout. Clearances between the spout weight and the cage permit the required relative movement for spout alignment. The fins on the cone-valve stem opposite the delivery tube-spout interface (Figure 5) approximately center the valve below the canister opening.

\section{POWER SCREW AND CONE VALVE}

The power screw shown in Figure 7 and illustrated in Figure 8 actuates the cone valve and spout. The power screw is advanced up and down by a nut. 


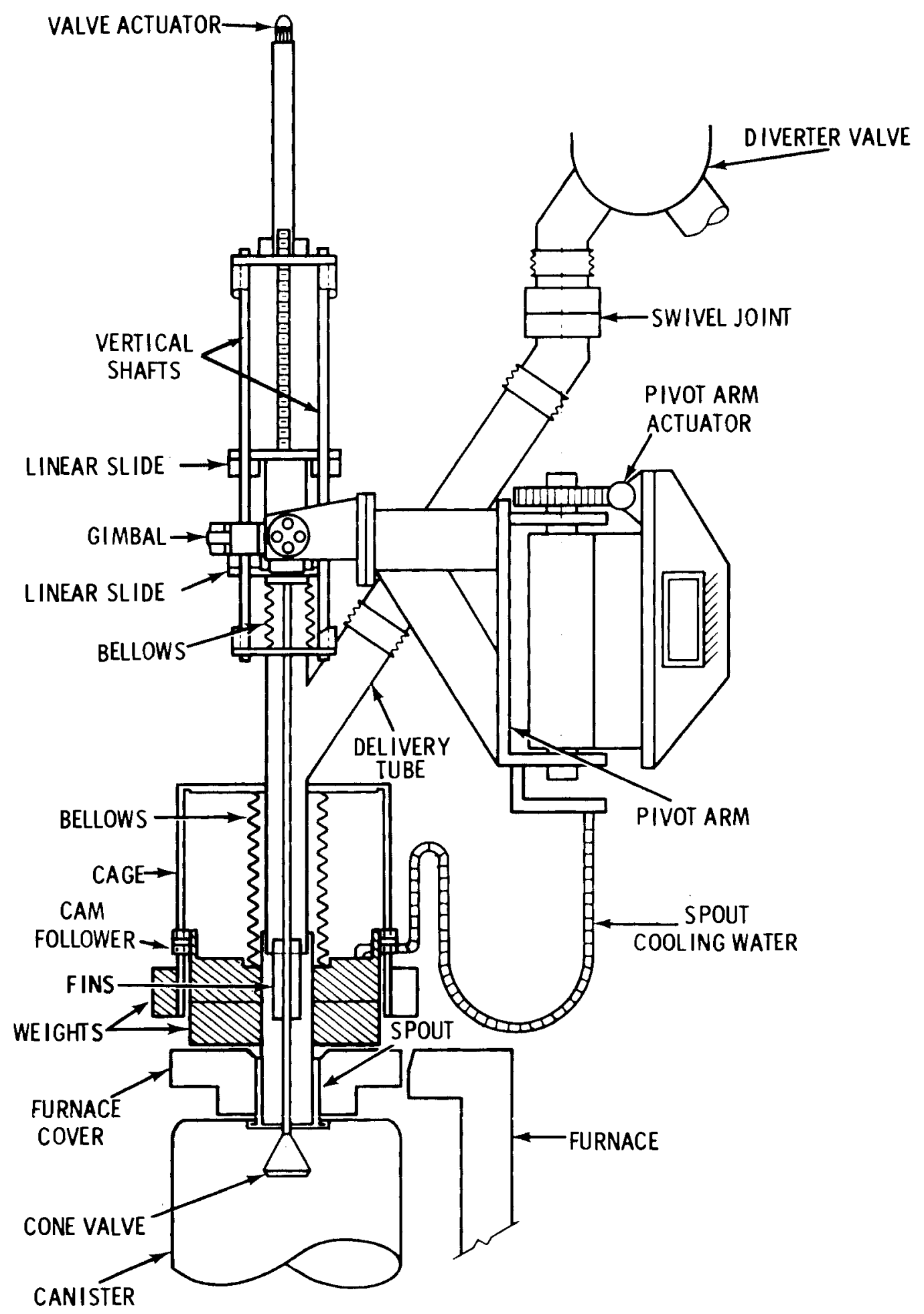

FIGURE 5. Conceptual Connecting Section Mechanism 


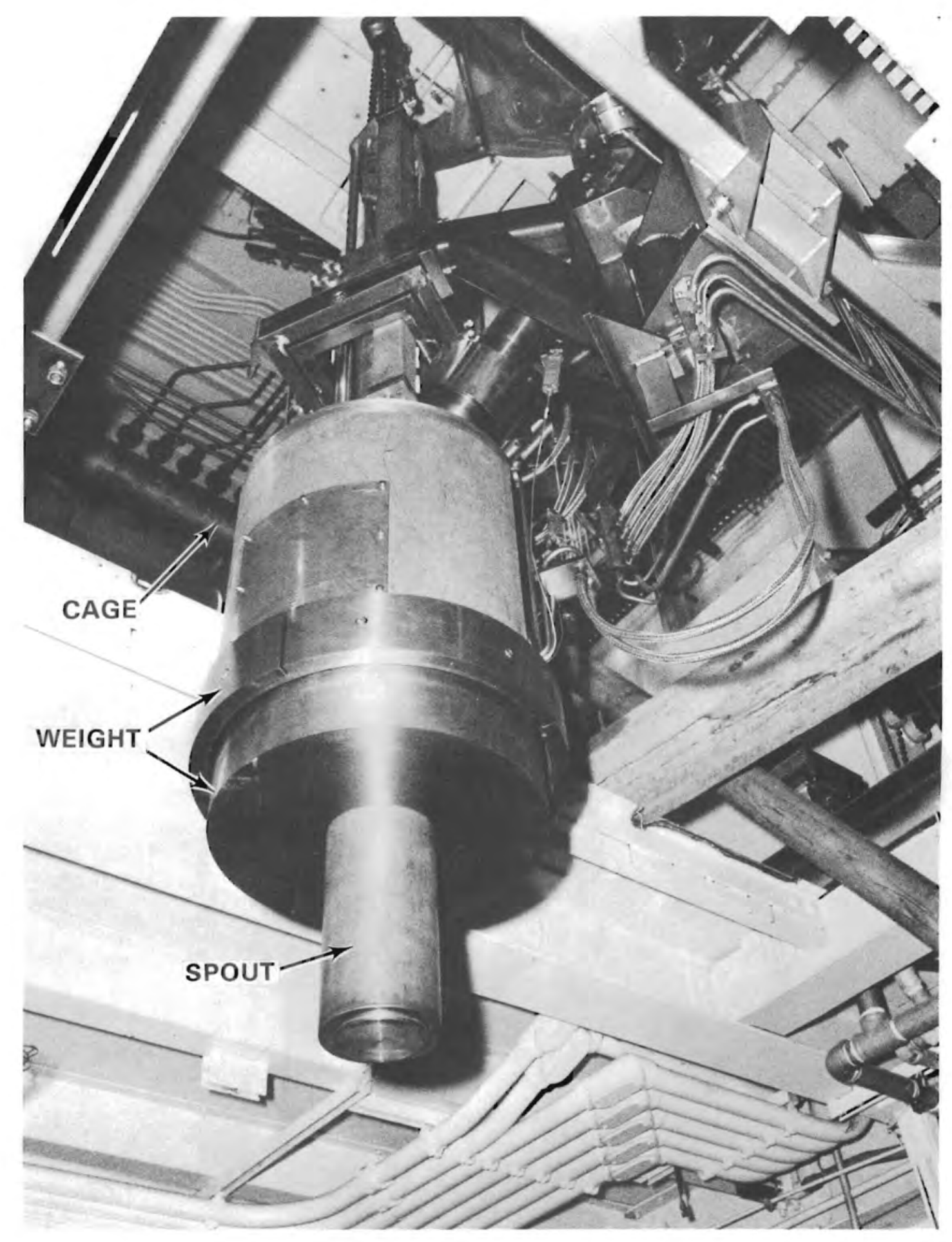

FIGURE 6. Cage and Extended Spout 


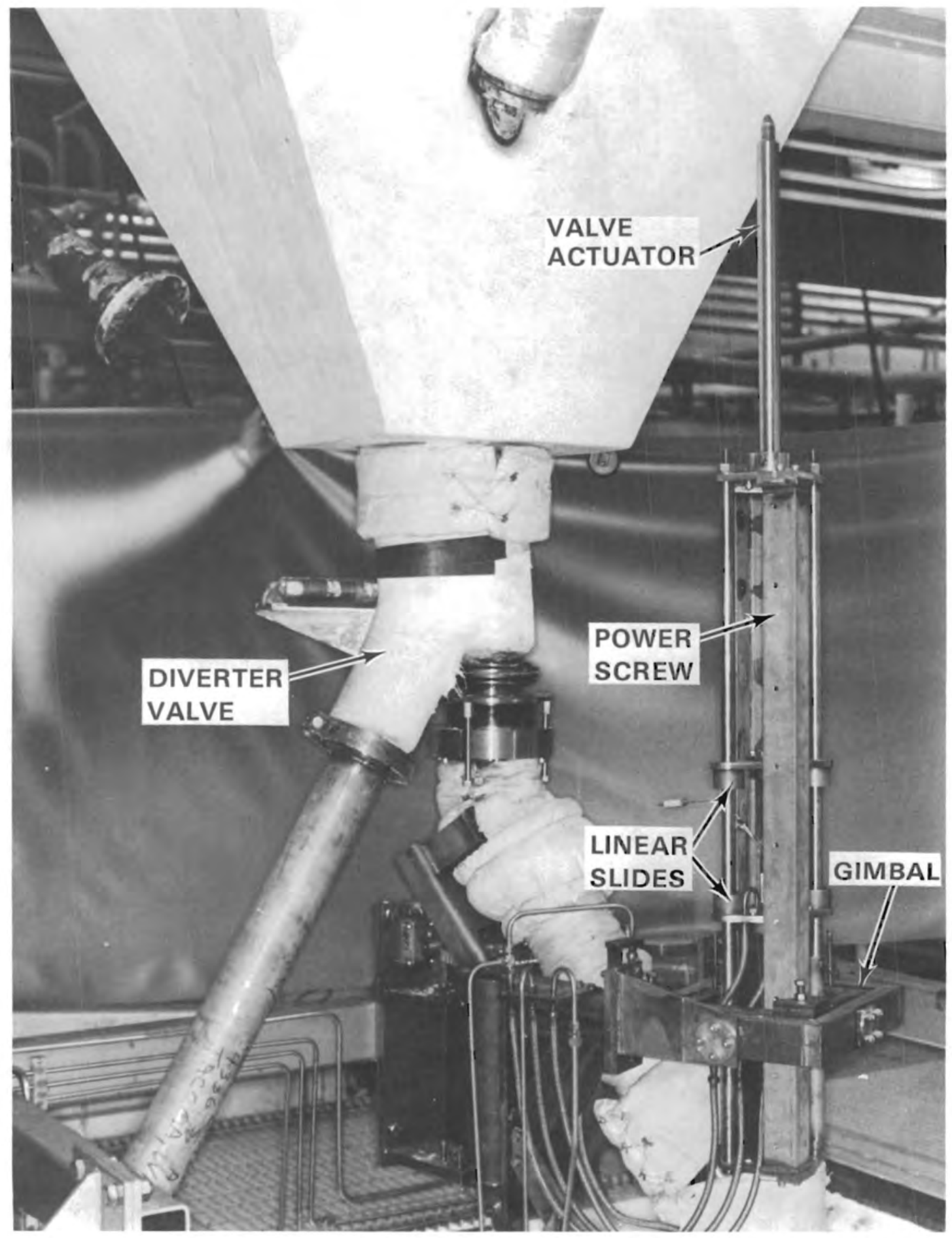

FIGURE 7. Upper Portion of the Connecting Section 


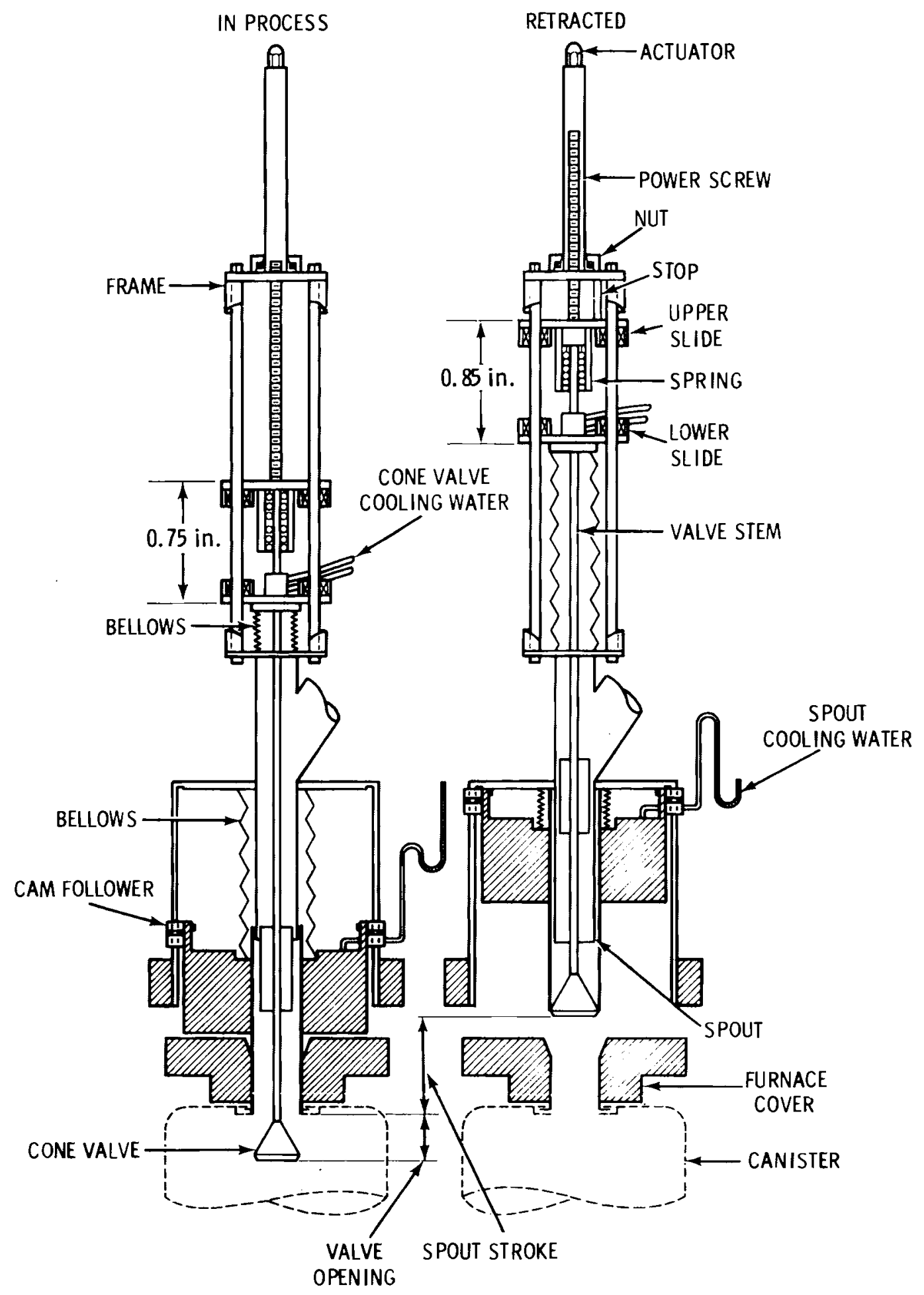

FIGURE 8. Conceptual Spout and Cone-Valve Assembly 
The nut, retained by thrust and radial bushings on the connecting-section frame, extends vertically with a tube that facilitates screw travel. An external torque source, such as an air or electric wrench, is positioned by an overhead crane to actuate the screw; the torque connection is at a fixed elevation for this purpose.

The power screw is attached to an upper slide that mounts a spring housing. Piston action on a compression spring retained in the housing connects a lower slide to the upper slide. The cone-valve stem is in turn attached to the lower slide. A closeup of these components is shown in Figure 9. This arrangement provides a visual indication of the spout-to-canister seal before the cone valve is opened. Also, the arrangement provides an indication of the amount of cone-valve opening, which is accomplished in the following sequence:

1) In the retracted position, the upper slide (Figure 8 ) is raised to a stop. In this position, the weighted spout is fully supported by the cone valve, providing a metal-to-metal seal at the tapered conevalve interface. The spring is compressed $\sim 3 / 4$ in. by the suspended weight, and the upper and lower slides are at their greatest separation.

2) Slide separation remains unchanged as the spout is lowered through the furnace cover, until contact is made with the canister. Further lowering of the upper slide expands the spring and gradually transfers the spout weight to compress the canister seal. During this time, the elevation of the lower slide remains unchanged. This elevation may be predetermined to verify that the spout is in contact with the canister seal.

3) When the s?ides approach the ir least separation, the incremental weight gain on the system should substantially equal the 507-1b spout weight. Further actuation will then lower both slides and open the cone valve. The additional travel of the lower slide below its elevation at weight transfer determines the amount of cone-valve opening. 


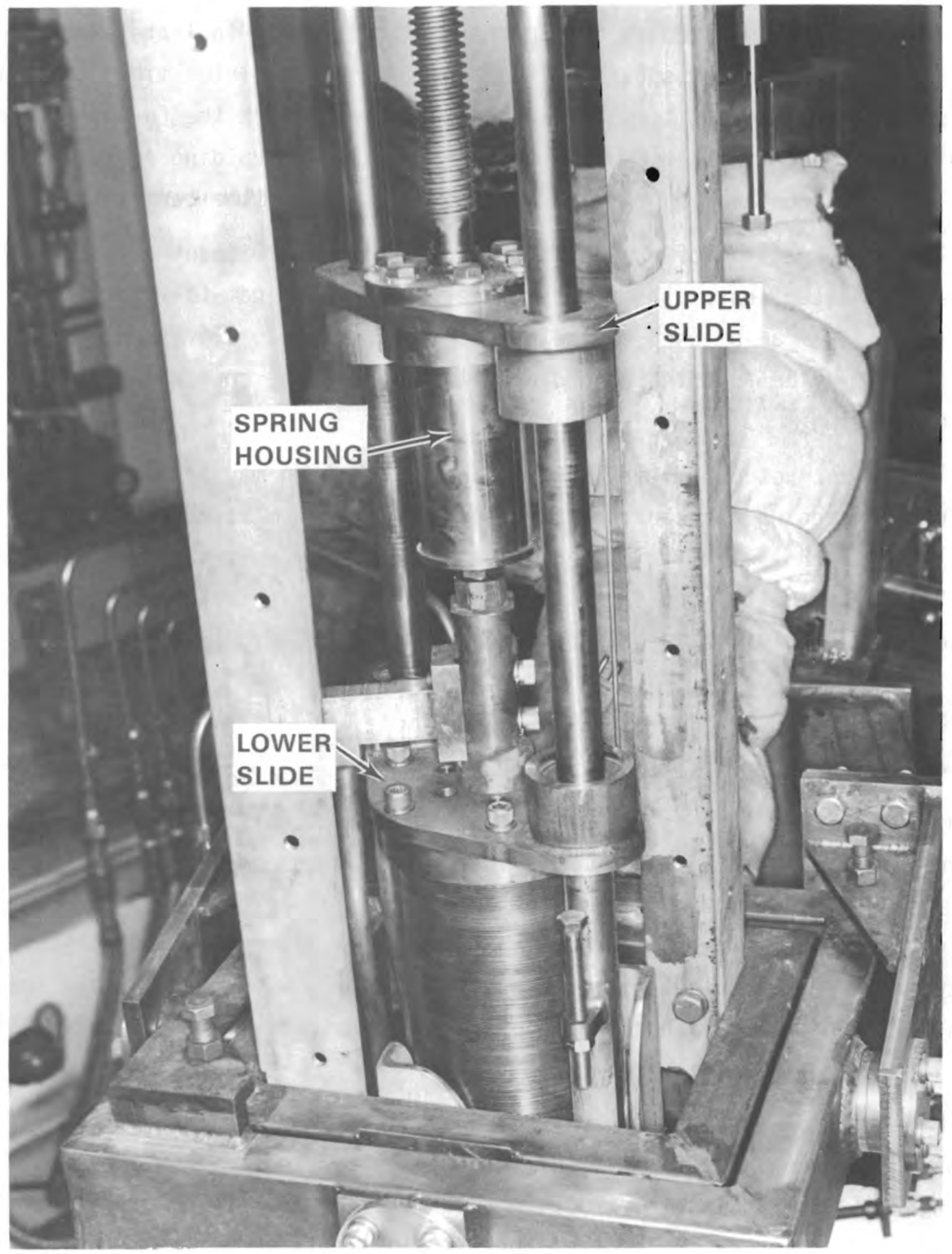

FIGURE 9. Cone-Valve Actuation Assembly 
A premature reduction in slide separation (before the lower slide reaches. its elevation for spout contact with the canister) would indicate excessive misalignment between the spout and the cover. This condition might exist if the delivery tube were not fully pivoted to the center of the furnace cover. In this event, the indicator would provide a means of avoiding accidental opening of the cone valve prior to sealing the spout to the canister.

Thermal expansion of the canister lifts the spout without affecting the spout-to-canister seal. The relative elevation of the cam-follower on the cage (Figure 8) can be used to indicate this expansion: Elevation of the lower slide may be adjusted accordingly to maintain the cone valve at the desired opening.

In the retracted position, the connecting section may be pivoted to clear the furnace opening for canister exchange. A pivot arm is mounted on the vertical axis of the swivel joint and driven through a worm gear as shown in Figure 10. A nut on the worm shaft permits pivot operation by an external torque source positioned with the overhead crane.

\section{CONNECTING SECTION/CANISTER INTERFACE SEAL}

The two primary requirements of the connecting section are to prevent the release of calcine into the cell and to maintain a partial vacuum in the delivery system to facilitate offgassing. These requirements call for a positive, dust-tight seal to be made to the canister before the spout is opened, and conversely, closing of the spout before the canister seal is broken. This is accomplished, in a sequence previously described, with the weighted spout, which is supported by either the cone valve or the canister, and a resilient, metallic "E"-seal at the canister interface.

Figure 11 illustrates the connecting section/canister interface at transition. The cone valve forms a metal-to-metal, tapered seal in the spout opening while supporting the spout, whereas the "E" seal is compressed while the spout is supported by the canister. During transition, the resiliency of the "E" seal provides closure continuity by forming (or conversely retaining) a seal with the spout before the spout weight is fully transferred. 


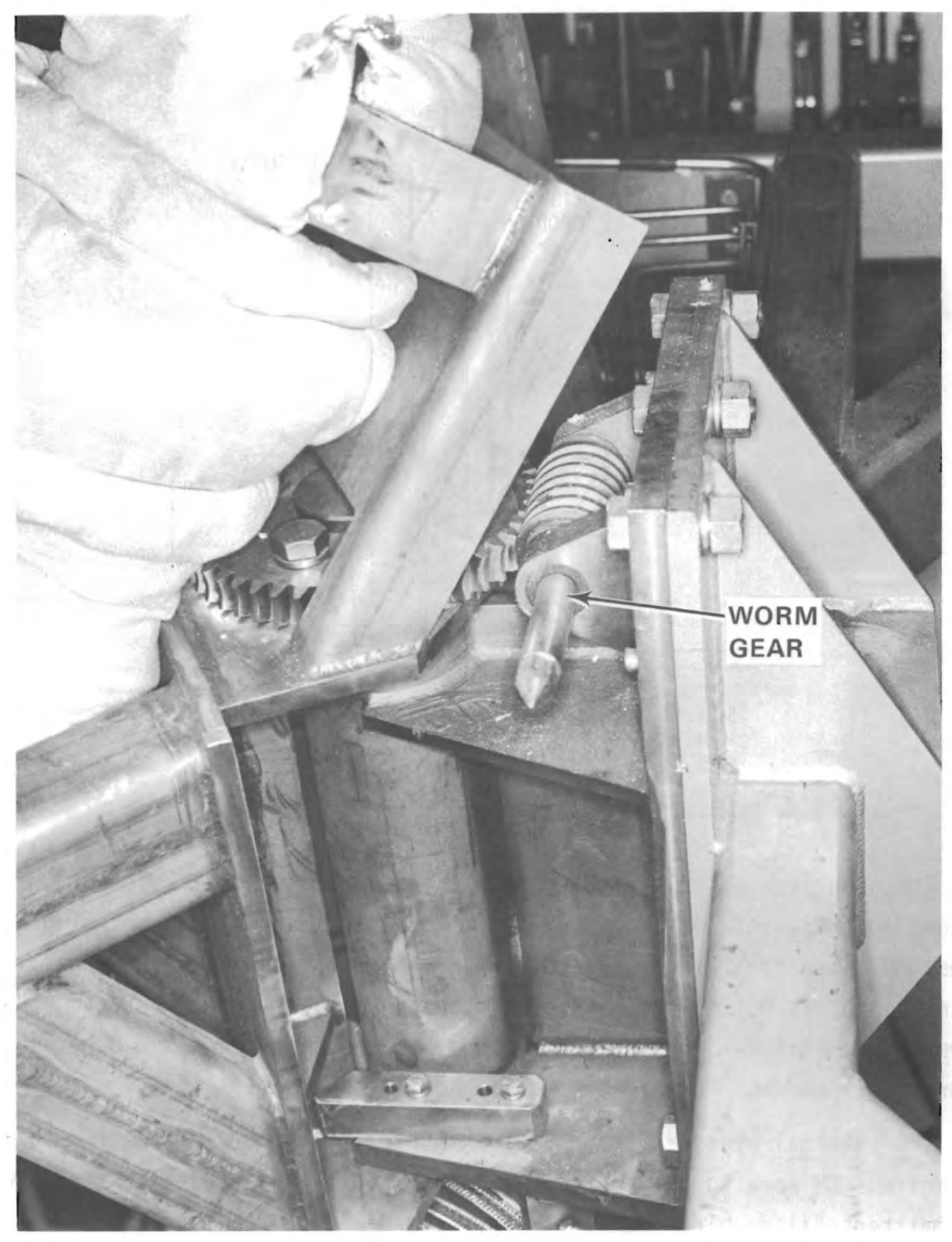

FIGURE 10. Pivot Arm Actuator 


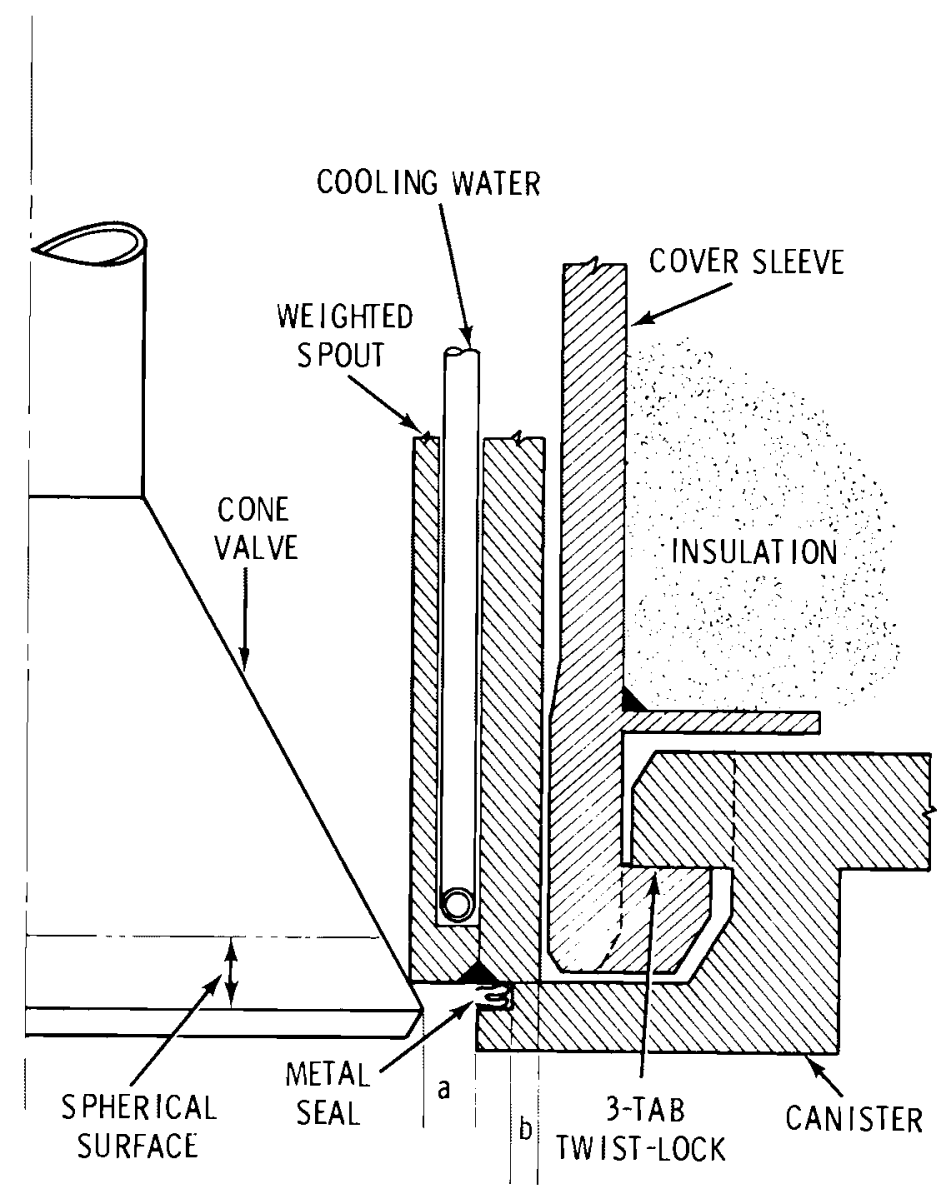

FIGURE 11. Connecting Section/Canister Interface

The spout is radially aligned with the seal by the cover sleeve, which is engaged in the twist-lock connection of the canister opening. Location clearances and dimensional tolerances of these components are such that the minimum clearance "a" is $0.129 \mathrm{in}$. (Figure 11) to assure free movement of the cone valve in the canister opening. The minimum contact surface "b"--0.041 in.-assures full contact between the spout and the "E" seal.

The internal-pressure Inconel $718^{\circledR}$ "E"-seal (Blair 1979) was identified in earlier ICM work to prevent powder leakage at the canister interface during intermittent filter blowback, which may generate a sudden, slightly positive pressure in the normally negative pressure system. The seal also compensates

${ }^{\circledR}$ Huntington Alloys Division of the International Nickel Company, Inc., Huntington, West Virginia. 
for machine tolerances and thermal distortion of the interface surfaces. The seal is held captive in a groove in the canister lid, having been sprung slightly out of round and forced into the groove before the canister is moved to the process area.

Excessive thermal distortion of the canister flange is a potential problem related to this interface design. Thermal gradients through the flange are appreciable because of its contact with the water-cooled spout. Therefore, it is important that the spout be in complete peripheral contact to maintain uniform temperatures to prevent distortion of the canister flange in excess of available seal defection. Seal defection is only 0.015 to 0.029 in. as determined from seal free-height and groove depth. Therefore, the "floating" spout concept was incorporated to provide complete interface contacts over the limits of possible canister misalignment. The lower surface of the cone valve is spherical for the purpose of seating to a slightly tilted spout. 

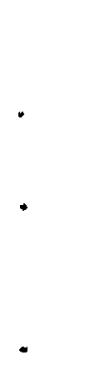


\section{CANISTER SUPPORT AND ALIGNMENT CONCEPT}

The connecting section spout is designed to align with any position of the canister opening within the limits defined by the canister support system. As described earlier, the canister is supported on the bottom of the ICM furnace between centering guides and radially contained in the furnace opening by the engaged cover. Figure 12 illustrates this concept.

Furnace-bottom irregularities, squareness of the canister base, thermal warpage of the canister, allowances for canister and cover thermal-expansion, and canister removal clearances contribute to the potential for misalignment of the canister within these supports. Worst-case misalignment occurs when the canister is against a centering guide, tipped in a direction opposite the guide and restrained by the cover against the furnace opening as shown in Figure 12 .

In the illustration, in worst-case misalignment the cover axis is at an angle with the canister axis because of assembly clearances in the twist-lock coupling. Angle $\alpha$, plus clearances $y$ and $z$, allow the canister to tilt at an angle with the furnace axis. Since misalignment is nondirectional, displacement of the canister axis at the seal interface (seal axis) falls within a circular area. Figure 13 illustrates the resulting limits of seal-axis position and gives the values of angle $B$, displacement $R$, and canister thermal expansion used in the design of the connecting section for demonstration purposes. The inside diameter of the furnace cover is tapered by at least angle a (determined to be $0.79^{\circ}$ for the demonstration design) to allow spout alignment with the seal axis.

\section{ACCOMMODATION OF CANISTER MISALIGNMENT AND EXPANSION}

The connecting section accommodates canister misalignment and thermal expansion by means of a weighted spout that "floats" with the canister. Figure 14 is an exaggerated illustration of this capability. As previously described, the weight of the spout causes it to assume the seal axis of the canister and to compress the interface seal. However, when seated on a tilted 


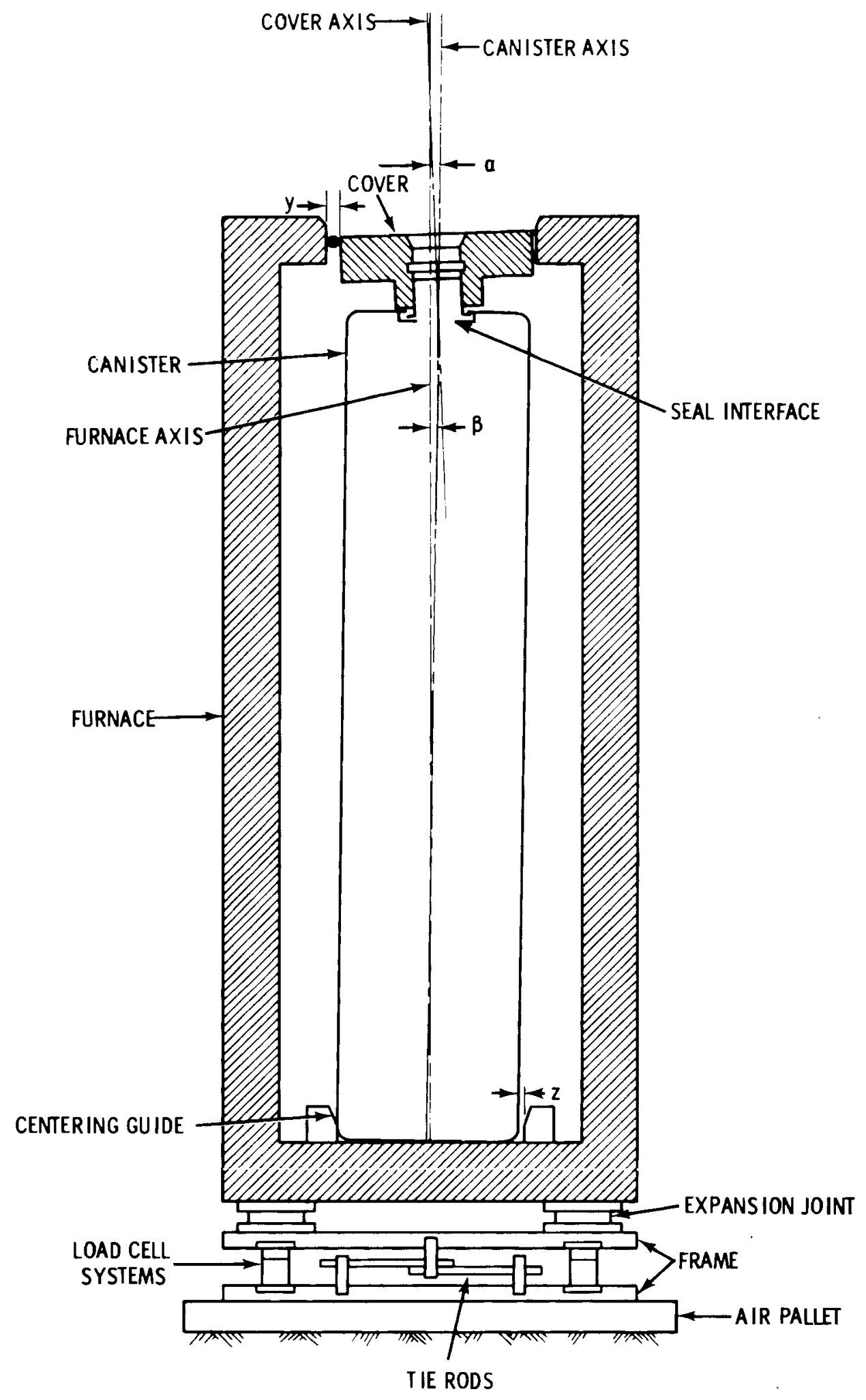

FIGURE 12. ICM Canister Support Concept 


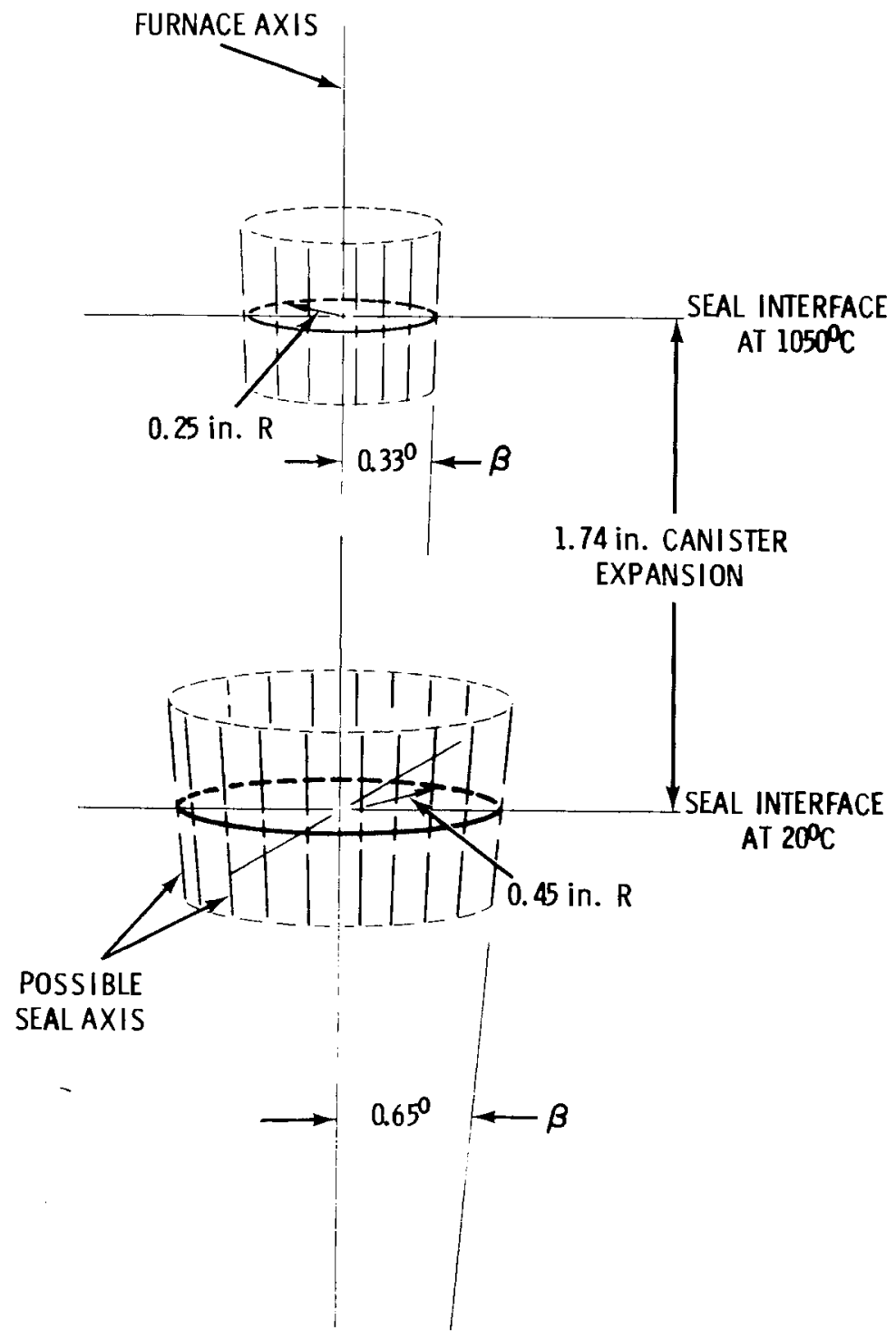

FIGURE 13. Limits of Possible Seal Axis Position

canister, the spout's weight vector is displaced from the axis of the seal. This displacement results in a tipping moment on the spout and a corresponding nonuniform peripheral force on the seal.

To counteract this tipping moment, and to facilitate the "floating" of the spout, the vertical section of the delivery tube and associated mechanism are supported through a gimbal, as described earlier. The weight and 


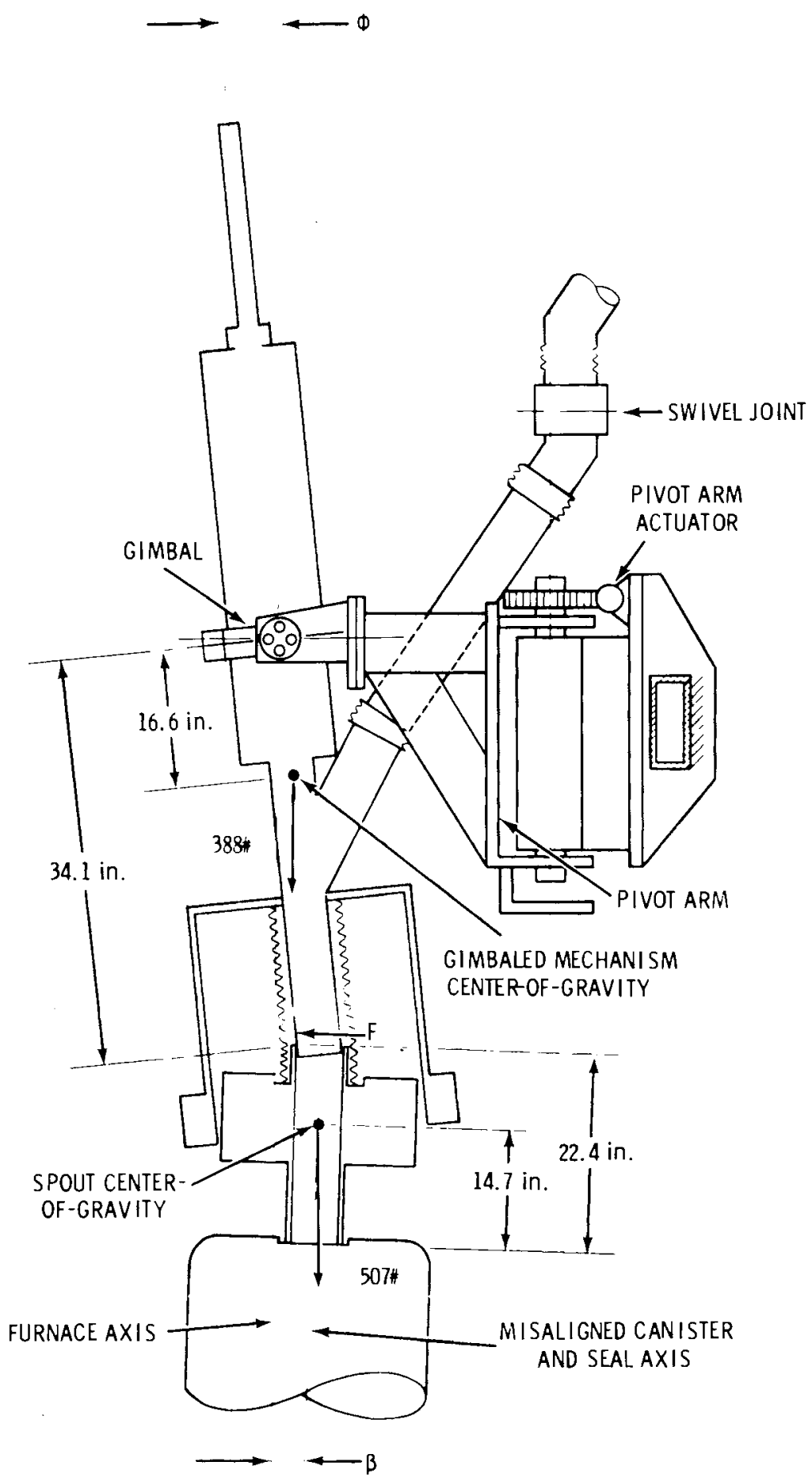

FIGURE 14. Accommodation of Connecting Section to Canister Misalignment 
center-of-gravity of the gimbaled components are sized and located such that any lateral displacement of the delivery tube by the spout results in a force, $F$, on the spout that is opposite to the direction of spout tilt. The corresponding counter-moment on the spout approximately cancels the spout tipping moment, thereby tending to equalize peripheral force on the seal.

Spout weight is determined from the seal manufacturer's(a) force-deflection curve, which indicates that $228.5 \mathrm{lb}$ per circumferential inch is required to compress the selected "E"-seal cross section a nominal 0.22 in. Therefore, 507-lb spout is required for the 5.658-in.-dia interface seal.

Furnace cover thickness, depth of canister submersion in the furnace, and spout weight are the principal determinants of the spout's center-of-gravity, which is located $14.7 \mathrm{in}$. above the interface seal. When the canister is at the worst-case tilt angle $\beta$ of $0.65^{\circ}$ (see previous section), the tipping moment of the spout is $\sim 85$ in. $-1 b$.

Counter moment resulting from displacement of the gimbaled mechanism may be approximated from the design data given in Figure 14 . For example, a canister tilt of $0.65^{\circ}$ tilts the gimbaled mechanism $1.18^{\circ}$ (angle $\phi$ ) and displaces the 388-1b gimbaled weight. The resulting force, $F$, is $23.9 \mathrm{lb}$, which provides an 88-in.-lb moment counter to spout tilt.

A number of variables affect the actual counter moment of the spout. These include friction of the gimbal bushings, spring rate of the bellows in the delivery tube, sleeve friction at the interface of the delivery tube and spout, sleeve friction in the slope tube, thermal expansion of components, and lateral deflection of the bellows attached to the spout. Their combined effect is estimated to be as much as $\pm 30 \%$ of the approximate value of counter moment calculated. Although potential variation of counter moment is appreciable, the overall effect of the design is to reduce (rather than magnify) spout-tipping moment.

(a) Pressure Science Inc., Catalogue No. 684A9-0084A, Beltsville, Maryl and. 


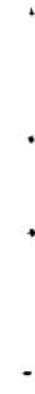




\section{WEIGHING SYSTEM DESCRIPTION}

The weighing requirements for ICM process control are to monitor the rate of batch flow into the canister and to indicate the total batch weight accumu1ated. Design process batch $\mathrm{flow}$ is $21-1 / 2 \mathrm{lb} / \mathrm{min}$. Previous attempts to measure this rate, using a resistance-load cell system sized and arranged to weigh the canister and delivered batch only, were unsuccessful because friction between the canister and furnace caused fluctuations of several hundred pounds.

To avoid this problem, the canister, delivered batch, furnace, cover, and connecting section spout (totaling $\sim 12,000$ lb) are jointly weighed by two parallel systems. Since the spout floats with the canister and is bushed at its interface with the delivery tube, frictional forces affecting the weighing system are estimated to be $<0.4$ lb. A resistance-load ce 11 system measures total weight for the deduction of accumulated batch weight and a piezoelectricload cell system directly monitors the rate of weight gain or batch flow rate. The load cell systems are mounted in a common frame and are isolated from lateral forces by expansion joints and a system of tie rods, as illustrated in Figure 12 .

The resistance-load cell system is made up of four low-profile cells (Interface, Inc. Model 1210-AF) each with a bridge sensor (Calex Mfg. Co. Model 165) for excitation and signal conditioning. Each cell has a 5,000-1b range; their outputs are algebraically summed by a computer to indicate accumulated batch weight.

The piezoelectric-load cell system is made up of four piezoelectric-load washers, associated mounting hardware, cables, junction box, and charge amplifier (Kristol Instrument Corp.). The system provides a combined weight-gain output. When acted upon by an external force, the piezoelectric crystal emits a charge that is proportional to the force applied but independent of preload. Therefore, the system is sensitive to the relatively small rate of batch flow in the presence of the large static load of the canister, furnace, cover, spout, and accumulated batch. 


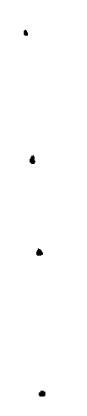




\section{DEMONSTRATION RUN RESULTS}

As described in this report, the connecting section and canister support and weighing systems demonstrate potential technical feasibility in remote operations. Their design would facilitate, for process control, the monitoring of batch weight. Also, throughout demonstration runs, the desired seal at the canister interface was remotely accomplished and maintained. In addition, canister misalignment in the furnace and thermal expansion of the canister, furnace, connecting section, and delivery system (although not measured) were accommodated without noticeable effect upon the weighing system. The following evaluations of the operations of specific components are offered as a basis for future developmental effort.

\section{FURNACE COVER}

The fabricated furnace cover successfully provided the desired submersion and alignment of the canister in the furnace hot zone, and alignment of the spout to the canister/seal interface. No apparent thermal damage to the cover was noted during the eight thermal cycles the cover experienced.

Although the cover freely disengaged from the filled canister, the hot cover would not engage with a cold canister due to thermal expansion of the cover sleeve. The outside diameter of the sleeve and the inside diameter of the canister lugs are dimensioned for a 0.105- to 0.145-in. clearance to provide the desired center of the spout to the canister seal. For this purpose, the conceptual plan requires two or more covers to allow for sleeve contraction before engagement with the next canister. Only one cover was fabricated for the demonstration.

\section{WEIGHING SYSTEM}

The weighing system concept proved to be successful; however, not all elements of the system performed satisfactorily. The floating spout and bellows concept liberated the load cells from any thermal expansion problems. Furnace movement on the air pallet was accommodated by the isolation frame, 
which prevented side loads from over-stressing the load cells. The furnace total weight was given by the load cells, and this data corresponded well with the frit and calcine addition rates. The load cells also produced information on malfunctions in the frit feeding system during different runs, which is, of course, the purpose of the weighing system. The piezoelectric force transducers have not yet produced any useful data. The transduce internal time constant and the intermittent nature of the ICM fill cycle produced an incoherent output. Also, the sensitivity of the piezoelectric crystals appears to have picked up vibration and noise external to the system. We hope that electronic filtering and more sophisticated computer techniques can sort out the information and redeem the promise of a high sensitivity to incremental weight gain, which would be invaluable in melter process control.

\section{BELLOWS}

The bellows in the vertical leg of the delivery tube have shown themselves to be nominally workable but do have potential problems which could considerably shorten their useful life. More experience with the bellows would be necessary to arrive at a final verdict on their use, and other efforts seem to be advised. Difficulties were experienced in fully retracting the spout during the second and subsequent canister exchanges during the 5-d demonstration run. For approximately the last 2-1/2 in. of stroke, the force required to retract the spout was estimated to be in excess of $1800 \mathrm{lb}$.

After the run, examination of the bellows between the spout and delivery tube disclosed that the lower 4 in. was wedged in its extended position with calcine powder. Approximately 25 to 30 convolutions opposite the thimble were affected. The thimble houses a bearing sleeve and extends the spout 5.25 in. up inside the bellows to engage and telescope on the deiivery tube. A 0.16in.-dia clearance at this bearing interface facilitates spout alignment with the canister but also allows suspended calcine to enter the bellows area and accumulate between the bellows and the thimble. The bellows above the 25 to 30 expanded convolutions contained dry powder at a thickness estimated to average 0.013 in. per convolution. However, we have no reason to conclude that more powder would not accumulate during long-term operation. 
For subsequent runs, the thimble sleeve was removed and calcine powder fell out, which rendered the bellows fully operational. The transition area was beveled to facilitate the engagement of the telescoping tubes. This arrangement will surely limit the misalignment capability of the system, and it exposes the bellows to any problems that may occur. For example, if wet calcine cakes up in the bellows convolutions it may cause irreparable damage. The range of environments and problems that must be endured by other bellows in the connecting section is implied by the design of these bellows.

The bellows sealing the cone-valve stem to the connecting section also accumulated considerable moist powder during the 5-d run. Powder up to $3 / 8$ in. in thickness was found in the upper 5 to $8 \mathrm{in}$. of the bellows and on the underside of the valve-stem $f l$ ange. This accumulated powder did not noticeably affect the cone-valve operation because this bellows is compressed during the time calcine is fed into the canister. However, because of the severity of accumulation, it is anticipated that material will eventually fall into the extended bellows and reduce cone-valve stroke. Two methods might alleviate powder accumulation as a result of the presence of moisture: 1) controlling the temperature of the bellows and adjacent components--to $\sim 200^{\circ} \mathrm{C}$, and 2) periodic air purging.

The bellows in the sloped tube and above the swivel joint are not accessible for visual examination. However, based upon the grating noise heard as these bellows were fully compressed, accumulation of powder is evident. This suggests the possibility that over a longer period of operation these bellows would also become clogged with powder and thereby prevent the desired seal between the connecting section and a misaligned canister.

\section{CONE VALVE AND SPOUT COOLING}

Cooling in the cone valve and spout is provided to control the temperature gradient between the melter furnace and the calciner, and the cone valve and spout were designed for double containment of cooling water within the hot zone of the furnace. This was done to enhance the safeguards against potentially undetected leakage, although the need for this was not clearly 
established. The primary containment tubing was formed to fit snugly against the surface to be cooled. However, this approach and design were inadequate in obtaining the desired 300 to $400^{\circ} \mathrm{C}$ surface temperature. Initial heatup of the connecting section resulted in cone-valve temperatures of 665 to $810^{\circ} \mathrm{C}$ and a spout temperature of $765^{\circ} \mathrm{C}$ when the ICM furnace was stabilized at $1070^{\circ} \mathrm{C}$. The cone-valve and spout temperatures are excessive because calcine and frit stick to surfaces above $\sim 450^{\circ} \mathrm{C}$. In previous experimental work, the cone valve and spout were cooled by a single containment tubing of water. Based on this experience, and to meet the demonstration schedule, the cooled components were modified to flood their secondary confinement chambers.

To accomplish this, holes were drilled through the outer shell to intercept the cooling tube. Then, the shell holes were welded closed. In the cone valve, the inlet tube was intercepted with a hole through the base near its periphery, and the outlet tube with a hole at $\sim 2 / 3$ the height of the conical section (from the base). In the spout, the inlet tube was intercepted at its lowest position, and the outlet tube at its highest position $180^{\circ}$ opposite the inlet. These positions were selected to provide the best possible uniformity of water flow within the cooling chambers. The openings for the thermocouple leads were silver (15\%)-soldered closed, and on the spout several other components were welded together to completely seal the secondary system.

The temperature of the modified cooling system was limited to $\sim 100^{\circ} \mathrm{C}$ to keep the cooling water from vaporizing to steam in the line. However, to limit condensation, it was desirable to keep the cone valve as hot as possible, and the modified system provided an unexpected advantage. The entire cone valve was flooded but circulation was possible only in the cone itself. Although the temperatures in the flooded chamber were on $1 y 50$ to $80^{\circ} \mathrm{C}$, the stagnant hot water kept the cone valve much hotter than the temperature in any previous design. The temperature of the spout was $60^{\circ} \mathrm{C}$.

The surfaces of these components remained clean during the entire demonstration, except at one time when the claciner nozzle failed, dumping moist batch through the connecting section. The batch stuck to the cone valve, forming an insulation barrier sufficient enough to subsequently melt 
batch there. Interestingly, after the batch flow was interrupted, the accumulated batch fell away from the cone valve, suggesting a potential benefit of maintaining at least the conical surface of the cone valve at considerably below the targeted temperature of 300 to $400^{\circ} \mathrm{C}$.

During an ICM run of $1150^{\circ} \mathrm{C}$, the cone valve was used. However, as the furnace exceeded $1100^{\circ} \mathrm{C}$, the cooling-water temperature quickly rose from $\sim 70^{\circ} \mathrm{C}$ to almost $1100^{\circ} \mathrm{C}$. At that point a weld ruptured and the run was terminated. Investigations showed that a metal shaving produced during drilling to open the cooling coils had plugged at the cooling water outlet from the cone valve, causing the rapid temperature increase and failure. Subsequently, the cooling water entered the canister and vaporized. This sudden load on the calciner offgas system pressurized the calciner momentarily as the automatic system compensated for the load. At the time of the incident, the calciner had very little vacuum, 0 to 2 in. $\mathrm{H}_{2} \mathrm{O}$, since the calciner was in the heatup cycle. This low vacuum would not occur in normal operation. A normal operating vacuum would prevent, or at least mitigate, the minor pressure spike that occurred. The result of this incident suggests that the double containment requirement on the original design be eliminated.

At the conclusion of the 5-d run, calcine leakage was noted at the interface between the cone valve and spout. Leakage was limited to very fine powder and occurred even though a partial vacuum $\left(10-i n . \mathrm{H}_{2} \mathrm{O}\right.$ ) was maintained on the system. Examination of this interface disclosed some batch inclusion between the contact surfaces, and high spots on the cone valve. These high spots were approximately equally spaced from the plug weld in the base (where a hole had been drilled during the modification of the cooling system). The presence of this powder suggests that the intermediate conical surface was deformed during the weld, a typicai characteristic of $304 \mathrm{~L}$ stainiess steel. Another possible cause of deformation might have been the delivery of wet batch as described. Therefore, a material having greater thermal stability, such as Inconel, is recommended for the cone valve and spout. 
POWER SCREW

The method chosen for operation of the power screw, an impact wrench hanging from a crane, was simulated with handheld, air-powered impact wrenches for the demonstrations. Two sizes (64 ft-1b and $224 \mathrm{ft}-1 \mathrm{~b})$ were tried. The $1 \mathrm{ar}-$ ger unit drove the nut faster and with less impact noise, but both units were excessively hard on the connecting section equipment. During three operations, the $304 \mathrm{~L}$ stainless-steel screw mated to a Nitronic-60 ${ }^{\circledR}$ nut galled severely. To continue the demonstrations, the parts were refabricated by mating a 17-4 (H-1150) stainless-steel screw against a Nitronic-60 nut. The combined screw and nut were lubricated and used for the duration of the testing.

The original pair of screw and nut was selected as a galling resistant combination. Literature (Schumacher 1976) indicates that under test conditions this pair would resist galling at a contact pressure $>50,000 \mathrm{psi}$. The calculated single-thread contact pressure on the power screw is $2160 \mathrm{psi}$. We conjecture that the intermittent pressure on the screw caused by the impact wrench produces much more severe conditions for galling than would otherwise be present. The use of an air motor and drive train to turn the screw would provide a much smoother, even torque, which would increase the life of the apparatus and allow nonlubricated operation. Also, other materials combinations could be used to reduce the galling tendency of these parts. Testing of such combinations would need to be done with the specific service in mind.

\section{THERMOCOUPLES}

Thermocouples were installed in the cooled sections of the spout and the cone valve, in addition to the vertical leg, which is the coolest and most vulnerable section. The thermocouples in the spout and cone valve were in the fiooded areas and only read coolant temperature; the area of interest is the outer skin, which absorbs the radiant heat from the furnace. Localized hot

${ }^{\circledR}$ Trademark of Armco Steel Corporation, Advanced Materials Division, Baltimore, Maryland. 
spots on these outer surfaces can cause sticking of the powder and eventually plugging. Therefore, a thermocouple was welded to the inside wall of the cone valve. This thermocouple indicated temperatures very close to the bulk coolant temperatures, which suggested that the metal surfaces were sufficiently cooled. Thermocouples in the vertical leg were placed on the inside of the tube to register a more accurate process temperature. However, these thermocouples never indicated much activity in the connecting section. In fact, when damp batch was produced in the calciner, no trouble was indicated by the thermocouples. 



\section{CONCLUSIONS}

Based on the results of the demonstration runs, we conclude that the concept design is an acceptable method of connecting the two pieces of process equipment together. Although the connecting section has not been optimized in all areas of concern, it provides a first-generation design of a productionoriented system.

More specific results of the demonstration runs are as follows:

- The original, closed bellows design of the connecting section's flexible and telescoping elements accumulated calcine to the extent that operation was impeded. The flexible bellows provided for the alignment at the spout/canister interface during the entire demonstration. The modified, open bellows allowed free operation of the telescoping leg during the last two canister changes. The reliability of the bellows, however, is questionable.

- The cone valve failure was handled adequately by the calciner offgas system. This indicates that single containment of cooling water will be adequate in the connecting section.

- Spout and cone valve coolant temperatures of $60^{\circ} \mathrm{C}$ to $70^{\circ} \mathrm{C}$ produced a noncondensing environment in the connecting section, and no plugs were formed in this manner.

- The furnace weight gain system produced a good record of gross weight, but the hoped-for sensitivity of the incremental weight gain system has not produced any meaningful data. The gross weight readings indicate that thermal expansion and misalignment did not interferc with the weight.

- Remote connection of the connecting section to all of the canisters was completed as needed, and no problems were encountered with the canister seal.

- The gimbal has proved to be an effective alignment mechanism. 
- The actuating mechanism has higher than expected galling tendencies due probably to the intermittent nature of the power source (impact wrench). The galling tendencies must be reduced to increase reliability.

- Elevation constraints between the calciner and the melter imposed design compromises that preclude the direct use of the design in a remote facility. For instance, the length of the sloped tube is considerabiy shorter than that required to gain overhead-crane access to the actuator, and for canister exchange. Elevation constraints are also reflected in the design of the spout stroke and swivel joint. Accomodation of these restraints did not affect operation of the equipment but did restrict design flexibility. 


\section{REFERENCES}

Blair, H. T. 1979. Full-Scale In-Can Melter Demonstration for Vitrification of Nuclear Waste. PNL-SA-6768, Pacific Northwest Laboratory, Richland, Washington.

Blair, H. T., P. S. Gorton and H. L. Nelson. 1979. "In-Can Melting Development." In Quarterly Progress Report, Research and Development Activities Waste Fixation Program. PNL-3050-1, Pac if ic Northwest Laboratory, Richland, Washington.

Siemens, D. H. and W. F. Bonner. 1976. "Design Features of a Full-Scale High-Level Waste Vitrification System." In Proceedings of 24th Conference on Remote Systems Technology, Pac if ic Northwest Laboratory, Richland, Washington.

Schumacher, W. J. 1976. "Metals for Non-lubricated Wear." Machine Design. 
-

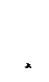

$+$ 


\section{ACKNOWLEDGMENTS}

The authors are indebted to D. N. Berger, W. F. Bonner, D. H. Siemens, Jr., S. C. Slate and R. L. Treat for their help, critique, and suggestions. In addition to the authors, major contributors to this task were: L. A. Strope and L. F. Shotwell--Weighing Systems and Components; P. C. Stover and T. J. Mathieu--Weighing Systems Computer Interface; A. N. Van Dan and S. D. Miller-Design and Drafting; and L. Sheldon--Purchasing.

Major suppliers included:

- Tool Gauge and Machine Works, Inc. (Fabrication and Assembly)

- Columbia Engineering Services, Inc. (Detail Drawing Package)

- Graphite Metalizing Corp. (Bearings)

- Metal Bellows Corp. (Bellows)

- The Advanced Products Co. (Metal Seals)

- Interface, Inc. (Load Cells)

- Kristol Instrument Corp. (Piezoelectric Load Cells). 


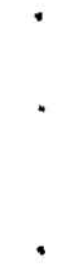




\section{$\underline{\text { DISTRIBUTION }}$}

No. of

Copies

\section{OFFSITE}

A. A. Churm

DOE Chicago Patent Group

9800 South Cass Avenue

Argorne, It 60439

2 R. Y. Lowrey

DOE Albuquerque Operations Office

P. 0. Box 5400

Albuquerque, NM 87185

A. L. Taboas

DOE Albuquerque Operations Office

P. 0. Box 5400

Albuquerque, NM 87185

S. A. Mann

DOE Chicago Operations and Region Office

Argonne, IL 60439

\section{J. 0. Neff}

Department of Energy

Columbus Program Office

505 King Avenue

Columbus, $\mathrm{OH} 43201$

W. E. Mott

DOE Division of Environmental Control Technology

Washington. DC 20545

J. P. Hamric

DOE Idaho Operations office 550 2nd St.

Idaho Falls, ID 38401

J. B. Whitsett

DOE Idaho Operations office 550 2nd St.

Idaho Falls, ID 83401
No. of

Copies

D. G. Boyer

DOE Nuclear Waste Management

Programs

NE-331, GTN

Washington, DC 20545

R. Chitwood

DOE Nuclear Waste Management

Programs

NE-341, GTN

Washington, DC 20545

C. R. Cooley

DOE Nuclear Waste Management Programs

NE-331, GTN

Washington, DC 20545

G. H. Daly

DOE Nuclear Waste Management

Programs

NE-322, GTN

Washington, DC 20545

J. E. Dieckhoner

DOE Nuclear Waste Management Programs

NE-321, GTN

Washington, DC 20545

C. H. George

DOE Nuclear Waste Management Programs

NE-342, GTN

Washington, DC 20545

C. A. Heath

DOE Nuclear Waste Management Programs

NE-330, GTN

Washington, DC 20545 
No. of

Copies

M. L. Lawrence

DOE Nuclear Waste Management Programs

NE-340, GTN

Washington, DC 20545

D. J. McGoff

DOE Nuclear Waste Management Programs

NEW, B-107, HQ

Washington, DC 20545

2 S. Meyers

DOE Nuclear Waste Management Programs

NE-30, GTN

Washington, DC 20545

G. Oerte1

DOE Nuclear Waste Management Programs

NE-320, GTN

Washington, DC 20545

5 A. F. Perge

DOE Nuclear Waste Management Programs

NE-301, GTN

Washington, DC 20545

R. W. Ramsey, Jr.

DOE Nuclear Waste Management Programs

NE-301, GTN

Washington, DC 20545

R. Romatowski

DOE Nuclear Waste Management Programs

NE-30, GTN

Washington, DC 20545

V. Trice

DOE Nuclear Waste Management Program

NEW, B-107, HQ

Washington, DC 20545
No. of

Copies

D. L. Vieth

DOE Nuclear Waste Management Programs

NE-332, GTN

Washington, DC 20545

2 S. W. Ahrends

DOE Oak Ridge Operations Office P. 0. Box E

Oak Ridge, TN 37830

D. E. Large

DOE Oak Ridge Operations Office P. 0. Box E

Oak Ridge, TN 37830

S. G. Harbinson

DOE San Francisco Operations Office

1333 Broadway

Oakl and, CA 94612

E. S. Goldberg

DOE Savannah River Operations Office

P. 0. Box A

Aiken, SC 29801

W. B. Wilson

DOE Savannah River Operations Office

P. 0. Box A

Aiken, SC 29801

R. P. Whitfield

DOE Savannah River Operations Office

P. O. Box $A$

Aiken, SC 29801

Los Alamos Scientific Laboratory

P. 0. Box 1663

Los Alamos NM 87544

J. B. Martin

Division of Waste Management Nuclear Regulatory Commission Washington, DC 20555 
No. of

Copies

D. B. Rohrer

Division of Waste Management

Nuclear Regulatory Commission

Washington, DC 20555

R. D. Smith

Division of Waste Management Nuclear Regulatory Commission Washington, DC 20555

R. E. Cunningham

Office of Nuclear Safety

Materials and Safeguards

Nuclear Regulatory Commission

Room 562, 7915 Eastern Avenue

Silver Springs, MD 20910

27 DOE Technical Information Center

J. A. Buckham

Allied-General Nuclear Services

P. 0. Box 847

Barnwe 11, SC 29812

A. Williams

Allied-General Nuclear Services

P. 0. Box 847

Barnwe11, SC 29812

J. W. Bartlett

The Analytical Sciences Corp.

6 Jacob Way

Reading, MA 01867

J. H. Kittel

Argonne National Laboratory

Office of Waste Management

Programs

9700 South Cass Avenue

Argonne, IL 60439

M. J. Steindler/L. E. Trevorrow

Argonne National Laboratory

9700 South Cass Avenue

Argonne, IL 60439
No. of

Copies

A. Brandstetter

Battelle Memorial Institute

Office of Nuclear Waste I solation

505 King Avenue

Columbus, $\mathrm{OH} 43201$

W. Carbiener

Battelle Memorial Institute

Office of Nuclear Waste

Isolation

505 King Avenue

Columbus, $\mathrm{OH} 43201$

N. E. Carter

Battelle Memorial Institute Office of Nuclear Waste

Isolation

505 King Avenue

Columbus, $\mathrm{OH} 43201$

P. L. Hofmann

Battelle Memorial Institute

Office of Nuclear Waste

Isolation

$505 \mathrm{King}$ Avenue

Columbus, $\mathrm{OH} 43201$

M. Kehnemuyi

Battelle Memorial Institute

Office of Nuclear Waste Isolation

505 King Avenue

Columbus, $\mathrm{OH} 43201$

Beverly Rawles

Battelle Memorial Institute

off ice of fuc iear Waste

Isolation

$505 \mathrm{King}$ Avenue

Columbus, $\mathrm{OH} 43201$

Research Library

Battelle Memorial Institute 505 King Avenue

Columbus, $\mathrm{OH} 43201$ 
No. of

Copies

R. Maher, Program Manager Waste Management Programs Savannah River Plant

E. I. Du Pont de Nemours \& Co. Aiken, SC 29801

W. H. Baker

E. I. Du Pont de Nemours \& Co. Savannah River Laboratory

Aiken, SC 29801

M. D. Boersma

E. I. Du Pont de Nemours \& Co. Savannah River Laboratory

Aiken, SC 29801

J. L. Crandall

E. I. Du Pont de Nemours \& Co. Savannah River Laboratory

Aiken, SC 29801

R. G. Garvin

E. I. Du Pont de Nemours \& Co. Savannah River Laboratory

Aiken, SC 29801

L. W. Meyer

E. I. Du Pont de Nemours \& Co. Savannah River Laboratory

Aiken, SC 29801

D. L. McIntosh

E. I. Du Pont de Nemours \& Co. Savannah River Laboratory

Aiken, SC 29801

S. Mirshak

E. I. Du Pont de Nemours \& Co. Savannah River Laboratory

Aiken, SC 29801

J. A. Porter

E. I. Du Pont de Nemours \& Co. Savannah River Laboratory

Aiken, SC 29801
No. of

Copies

A. L. Ayers

EG \& G Idaho

P. 0. Box 1625

Idaho Falls, ID 83415

G. B. Levin

$E G$ \& G Idaho

P. 0. Box 1625

Idaho Falls, ID 83415

R. Williams

Electric Power Research Institute

3412 Hillview Avenue

Palo Alto, CA 94304

J. L. Larocca, Cha irman

Engineering Research and Development Authority

Empire State Plaza

Albany, NY 12223

2 Environmental Protection Agency

Technological Assessment Division (AW-559)

Office of Radiation Programs

U.S. Environmental Protection Agency

Washington, DC 20460

D. M. Rosenbaum

Office of Radiation Programs

U.S. Environmental Protection Agency

1921 Jefferson Davis Highway

Arlington, VA 22202

J. R. Berretin

Exxon Nuclear Idaho

P. 0. Box 2800

Idaho Falls, ID 83401

G. L. Ritter

Exxon Nuclear Idaho

P. 0. Box 2800

Idaho Falls, ID 83401 
No. of

Copies

File Copy

Exxon Nuclear Idaho

P. 0. Box 2800

Idaho Falls, ID 83401

G. E. Benedict

General Atomics Co.

P. 0. Box 81608

San Diego, CA 92138

L. H. Brooks

Gulf Energy and Environmental Systems

P. 0. Box 81608

San Diego, CA 92138

3 J. Campbe 11

Lawrence Livermore Laboratory

P. 0. Box 808

Livermore, CA 94550

J. D. Tewhey

Lawrence Livermore Laboratory

P. 0. Box 808

Livermore, CA 94550

R. Roy

202 Materials Research Laboratory

Pennsylvania State University

University Park, PA 16802

C. J. Kershner

Monsanto Research Corporation

Mound Laboratory

P. 0. Box 32

Miamisburg, $\mathrm{OH} \quad 45342$

J. P. Duckworth

Plant Manager

Nuclear Fuels Services, Inc.

P. 0. Box 124

West Valley, NY 14171

R. E. Bl anco

Oak Ridge National Laboratory

P. 0. Box Y

Oak Ridge, TN 37830
No. of

Copies

J. 0. Blomeke

Oak Ridge National Laboratory

P. 0. Box $Y$

Oak Ridge, TN 37830

D. E. Ferguson

Oak Ridge National Laboratory

P. 0. Box Y

Oak Ridge, TN 37830

3 A. L. Lotts

Oak Ridge National Laboratory

P. 0. Box X

Oak Ridge, TN 37830

R. S. Lowrie

Oak Ridge National Laboratory

P. 0. Box $Y$

Oak Ridge, TN 37830

2 A. B. Martin

Rockwe 11 International

Energy Systems Group

8900 DeSoto Avenue

Canoga Park, CA 91304

H. Recht

Dept. 737-710

Atomics International Division

Rockwell International

Box 309

Canoga Park, CA 91304

W. S. Bennett

Rockwe 11 International

Rocky Flats Plant

P. 0. Box 464

Golden, CO 80401

Paul Hagen

Chemical Operations

Rockwe 11 International

Rocky Flats Plant

P. 0. Box 464

Golden, CO 80401 
No. of

Copies

D. R. Anderson

Sandia Laboratories

Albuquerque, NM 87185

0. E. Jones

Sandia Laboratories

Albuquerque, NM 87185

R. G. Kepler

Organic and Electronic

Dept. 5810

Sandia Laboratories

Albuquerque, NM 87185

W. Weart

Sandia Laboratories

Albuquerque, NM 87185

D. E. Harrison

Westinghouse Electric Corp.

P. 0. Box 355

Pittsburgh, PA 15230

P. B. Macedo

Keane Hall

Vitreous State Laboratory

The Catholic University of America

Washington, DC 20017

R. G. Post

College of Engineering

University of Arizona

Tucson, AZ 85721

L. L. Hench

Dept. of Materials Science and Engineering

University of Florida

Gainesville, FL 32611

Dr. Hayne Palmour III

2140 Bur lington Engineering Laboratories

North Carolina State University

Raleigh, NC 27607
No. of

Copies

$$
\begin{aligned}
& \text { F. K. Pittman } \\
& 3508 \text { Sagecrest Terrace } \\
& \text { Ft. Worth, TX } 76109
\end{aligned}
$$

\section{ONSITE}

5 DOE Richland Operations Office

S. Clark

P. A. Craig (2)

R. E. Gerton

H. E. Ransom

4 Rockwe 11 Hanford Operations

I. E. Reep

D. D. Wodrich (3)

UNC United Nuclear Industries

F. H. Bouse

Westinghouse Hanford Company

A. G. Blasewitz

90 Pacific Northwest Laboratory

S. M. Barnes

W. J. Bjork lund

H. T. Blair

W. F. Bonner

D. J. Bradley

D. W. Brite

R. A. Brouns

J. L. Buelt

R. L. Bunnell

J. R. Carrei i

J. G. Carter

D. B. Cear lock

L. A. Chick

T. D. Chikalla

M. O. Cloninger

R. D. Dierks

G. J. Exarhos 
No. of

Copies

Pacific Northwest Laboratory (contd)

J. W. Finnigan

W. J. Gray

C. R. Hann

M. S. Hanson

A. J. Haverfield

O. F. Hill

L. K. Holton

J. H. Jarrett

Y. B. Katayama

W. S. Kelly

R. S. Kemper

D. E. Knowlton

C. A. Knox

W. L. Kuhn

L. T. Lakey

D. E. Larson

J. M. Latkovich

R. 0. Lokken

G. B. Long (3)

R. P. Marshall

S. A. McCullough

J. L. McElroy

M. A. Mck inney

G. B. Mellinger

J. E. Mende]

J. F. Nesbitt

R. E. Nightingale

P. J. Pelto

R. D. Peters

L. L. Petkus (20)

A. M. Platt

D. L. Prezbindowski

F. P. Roberts

W. A. Ross

J. M. Rusin

D. H. Siemens

S. C. Slate

C. L. Timmerman

R. L. Treat

R. P. Turcotte
No. of

Copies

H. H. Van Tuyl

B. E. Vaughan

J. W. Wald/W. E. Weber

J. H. Westsik, Jr.

L. D. Willi ams

Technical Information (5)

Publishing Coordination EI (2) 
